Article

\title{
Experimental Study of Absorbent Hygiene Product Devolatilization in a Bubbling Fluidized Bed
}

\author{
Barbara Malsegna, Andrea Di Giuliano (D) and Katia Gallucci *(D) \\ Department of Industrial and Information Engineering and Economics (DIIIE), University of L'Aquila, Piazzale E. \\ Pontieri 1-loc. Monteluco di Roio, 67100 L'Aquila, Italy; barbara.malsegna@student.univaq.it (B.M.); \\ diiie.sac@strutture.univaq.it or andrea.digiuliano@univaq.it (A.D.G.) \\ * Correspondence: katia.gallucci@univaq.it; Tel.: +39-0862-434213
}

Citation: Malsegna, B.; Di Giuliano, A.; Gallucci, K. Experimental Study of Absorbent Hygiene Product Devolatilization in a Bubbling Fluidized Bed. Energies 2021, 14, 2399 https://doi.org/10.3390/en14092399

Academic Editor: Fernando Rubiera González

Received: 7 April 2021

Accepted: 20 April 2021

Published: 23 April 2021

Publisher's Note: MDPI stays neutral with regard to jurisdictional claims in published maps and institutional affiliations.

Copyright: (c) 2021 by the authors. Licensee MDPI, Basel, Switzerland. This article is an open access article distributed under the terms and conditions of the Creative Commons Attribution (CC BY) license (https:// creativecommons.org/licenses/by/ $4.0 /)$.

\begin{abstract}
This paper aims to investigate the usage of waste from Absorbent Hygienic Products (AHP) as a fuel for gasification or pyrolysis, two attractive routes to obtain valuable products and dispose of this kind of waste. The study experimentally investigated the devolatilization of coarsely shredded materials from diapers, in a laboratory-scale bubbling fluidized bed made of sand, as a representative preparatory step of the above-mentioned thermochemical conversions. Two versions of shredded materials were considered: as-manufactured diapers (AHPam, as a reference), and the cellulosic fraction of sterilized used diapers (AHPus). Results were presented, obtained from physical-chemical characterization of AHPam and AHPus (TGA, CHNS/O, proximate and ultimate analyses, XRF, ICP-AES, SEM-EDS), as well as from their devolatilizations at 500-600-700-800 ${ }^{\circ} \mathrm{C}$ under two different atmospheres (air plus nitrogen, or pure nitrogen as a reference). Generally, temperature influenced syngas composition the most, with better performances under pure nitrogen. At $700-800{ }^{\circ} \mathrm{C}$ under pure nitrogen, the highest syngas quality and yield were obtained. For AHPam and AHPus, respectively: (i) $\mathrm{H}_{2}$ equaled $29.5 \mathrm{vol} \%$ and $23.7 \mathrm{vol} \%$, while hydrocarbons equaled $14.8 \mathrm{vol} \%$ and $7.4 \mathrm{vol} \%$ on dry, dilution-free basis; (ii) $53.7 \mathrm{Nl}$ and $46.0 \mathrm{Nl}$ of syngas were produced, per $100 \mathrm{~g}$ of fuel. Overall, AHP emerged as an interesting fuel for thermochemical conversions.
\end{abstract}

Keywords: absorbent hygiene product; waste; gasification; devolatilization; pyrolysis; fluidized bed; diapers; cellulosic fraction

\section{Introduction}

Since recent years, research efforts regarding renewable and sustainable energy sources have been more and more intensified because of the complexity of current global energy issues and the urgency of global warming containment [1].

The world population is expected to increase up to more than 11 billion people by the end of the 21st century, geographically concentrated in the currently least developed regions of the world [2]. This will involve net economic growth in those regions, which will in turn cause the growth of world energy demand and the consumption of resources with attendant waste generation, if the current model of linear economy is kept [3].

In September 2018, the World Bank announced that global waste production was predicted to increase by $70 \%$ (referring to 2018) by 2050 [4], unless actions were taken to break the "take-make-waste" paradigm of linear economy. Humankind in 2018 (7.6 billion people) produced two billion tonnes of waste per year; therefore, the expected world population growth should be compensated by avoiding the current gross mismanagement of waste [3].

In this framework, the European Union (EU) has promoted thematic strategies regarding waste prevention and recycling, as well as regulations concerning the transition towards a circular and sustainable economy [5]. In this scenario, several governmental programs have sustained actions to contrast climate change, as recently required by the Paris Agreement and the subsequent Conferences of the Parties to the United Nations 
Framework Conventions on Climate Change [6-9]. The European Green Deal represents an important response to climate change, setting the final goal of EU climate neutrality by 2050; the EU aims to couple this goal with a new growth strategy and a just transition towards a modern, competitive and resource efficient socio-economic system [10].

The use of waste as a feedstock is fundamental in a circular economy for applications in energy and biofuel production, since it is one of the pillars of the 2030 Agenda for Sustainable Development and contributes to decarbonization and landfill diversion [11]. Thermochemical conversions may serve as an essential part of a sustainable, integrated waste management system, as they are suitable routes to produce energy and fuels from waste [12-14]. In the first place, thermal treatment plants can directly convert the chemical energy content of waste in power and heat [15]. In addition, thermochemical conversions such as pyrolysis and gasification allow obtaining more valuable fuels or chemical products (e.g., by catalytic conversions of syngas [16]), bringing in the advantage of a unified, efficient treatment applicable to different types of solid waste [12-15].

Although biomass utilization in thermochemical processes for energy and chemical production has been extensively studied in the literature $[1,17,18]$, analogue studies concerning solid wastes lead to less unitary conclusions because of the broader heterogeneity of waste materials. This causes the need to specifically study each given class of waste in order to develop the related waste-to-energy/fuel/chemicals chain. This necessity has indeed promoted the birth of various projects, such as: "optiCOM", an industrial project aiming to implement fluidized-bed gasification of several solid wastes at industrial scale; "Lig2Liq", a European research project co-funded by the Research Fund for Coal and Steel of the European Commission, which investigates the co-gasification of lignite with Solid Recovered Fuel (SRF) [13,19]; and more than sixty projects funded in the Biomass, Biofuels and Alternative fuel field, by the EU HORIZON 2020 program [20].

Absorbent Hygiene Products (AHP) constitute one of those class of waste, classified as a sanitary waste according to the European Waste Catalogue code (EWC, Directive 2000/532/EC). AHP consist of a broad set of products, including diapers for babies, sanitary protection pads, tampons, adult incontinence products and personal care wipes. AHP waste currently represents about $2-3 \%$ of municipal solid waste and $15-25 \%$ of the residual waste stream in some treatment facilities [21].

Nowadays, waste from AHP is quite challenging from the sustainability point of view, since it is usually disposed of via either landfill or incineration, losing its recycling potential [22]. This is a strong motivation of interest in studying possible alternative processes to better exploit this kind of waste. In the literature, some studies reported the separation of AHP waste into its different components, which can then be recycled into secondary raw materials with multiple potential uses (e.g., plastic, cellulose fiber plus super absorbent polymers) [23-25].

In view of the implementation of an integrated and sustainable management of AHP waste, pyrolysis and gasification may represent a viable process option because of their versatility concerning fed feedstock and uniformity of product classes (e.g., syngas or liquid hydrocarbons) [26-29]. In other words, AHP waste is a potential feedstock for thermochemical conversion pathways; this aspect appeared as worthy of a scientific investigation, considering what is stated above about the need of specific studies for the thermochemical conversion of each given kind of waste, and that waste from AHP has not been extensively utilized in this way yet (to our best knowledge).

The present work is the first attempt to fill this gap. The option of the thermochemical conversion of AHP waste materials was studied from the experimental point of view. Two different AHP waste materials were investigated: as-manufactured, coarsely shredded diapers, and the cellulosic fraction of sterilized, used diapers. Devolatilizations of samples from those AHP wastes were performed in a laboratory-scale bubbling fluidized bed made of sand, as a representative preparatory step of pyrolysis or gasification, respectively, intended as thermochemical conversions in the absence of oxidants or in the presence of sub-stoichiometric oxidants (in comparison to combustion) [30]. Physical-chemical 
characterization of investigated materials was presented and discussed, together with their devolatilization performances, evaluated in terms of syngas yield, carbon conversion, syngas composition and cold gas efficiency. Results were compared, from devolatilizations at different temperatures (from $500^{\circ} \mathrm{C}$ to $800^{\circ} \mathrm{C}$ ), and under fully anoxic or slightly oxidant atmospheres.

These investigations provided novel results concerning the behavior of AHP waste in thermochemical conversions based on fluidized beds, which could be exploited for both scale-up studies and model validations.

\section{Materials and Methods}

\subsection{Waste Materials from AHP for Devolatilization Tests}

Two raw materials were selected in this work: (i) as-manufactured, coarsely shredded diapers (AHPam), which represent an industrial post-production waste (Figure 1a); (ii) the cellulosic fraction of sterilized used diapers (AHPus), deriving from a diaper sterilization cycle, followed by the separation of organic and plastic fractions, which are both a postconsumer material (Figure 1b). AHPam and AHPus are classified according to the EWC code as sanitary waste.

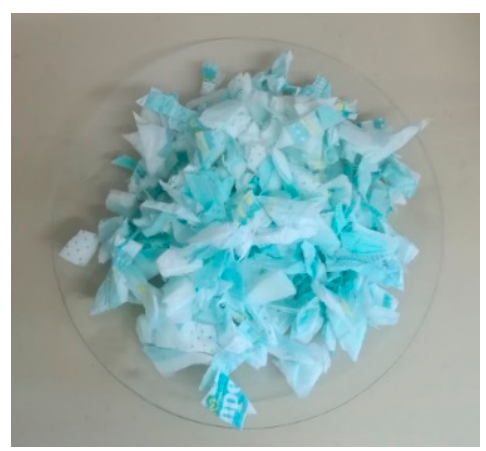

(a)

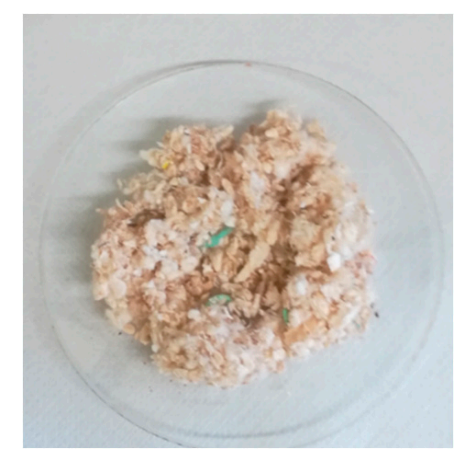

(b)

Figure 1. Coarsely shredded diapers (AHPam) (a); cellulosic fraction of sterilized diapers (AHPus) (b).

\subsection{Characterization of Waste Materials from AHP}

Several physical-chemical characterizations of waste materials from AHP were performed.

Proximate and ultimate analyses were determined by means of Thermo-Gravimetric Analysis (TGA), muffle test, oven test and elemental analysis, which quantified carbon (C), hydrogen $(\mathrm{H})$, nitrogen $(\mathrm{N})$, sulfur $(\mathrm{S})$ and oxygen $(\mathrm{O})$ (from here on named $\mathrm{CHNS} / \mathrm{O}$ ).

TGA tests were carried out by the Linesis STA PT100 equipment, to determine volatile matter and fixed carbon fraction. The tests were performed as specified by the standard ASTM D142/02 [31]. Three samples of AHPam and three of AHPus (masses in the range 13.0-27.0 mg) underwent TGA tests under pure $\mathrm{N}_{2}$ or air fluxes. The treatment under pure $\mathrm{N}_{2}\left(16 \mathrm{Nl} \mathrm{h}^{-1}\right)$ consisted of: (i) $10^{\circ} \mathrm{C} \mathrm{min}^{-1}$ heating rate from room temperature to $105^{\circ} \mathrm{C}$ and $15 \mathrm{~min}$ dwell at $105^{\circ} \mathrm{C}$; (ii) $10^{\circ} \mathrm{C} \mathrm{min}{ }^{-1}$ heating rate from $105^{\circ} \mathrm{C}$ to $950{ }^{\circ} \mathrm{C}$ and a $7 \mathrm{~min}$ dwell at $950{ }^{\circ} \mathrm{C}$. The treatment under air $\left(16 \mathrm{Nl} \mathrm{h}^{-1}\right)$ consisted of: (i) $10^{\circ} \mathrm{C} \mathrm{min}^{-1}$ heating rate from room temperature to $700{ }^{\circ} \mathrm{C}$ and $15 \mathrm{~min}$ dwell at $700{ }^{\circ} \mathrm{C}$; (ii) $10^{\circ} \mathrm{C} \mathrm{min}-1$ heating rate from $700{ }^{\circ} \mathrm{C}$ to $950{ }^{\circ} \mathrm{C}$ and $10 \mathrm{~min}$ dwell at $950{ }^{\circ} \mathrm{C}$. For each kind of treatment, blank tests were carried out and used to correct TGA data from actual samples.

Additional TGA tests were carried out, concerning combustion under air flux, in order to evaluate the temperature at which thermal oxidative phenomena could be considered as extinguished. For both AHPam and AHPus, TGA combustion tests were carried out under $10 \mathrm{Nl} \mathrm{h}^{-1}$ of air, heating from room temperature up to $950{ }^{\circ} \mathrm{C}$ at rates of 5,10 or $20{ }^{\circ} \mathrm{C}$ min $^{-1}$. 
Moisture fractions of AHPam and AHPus were determined by measuring the samples mass variation caused by a drying treatment in an oven (model MPIM factory Oven SL), keeping the temperature at $105{ }^{\circ} \mathrm{C}$ for $24 \mathrm{~h}$ (BSE EN 15414-3:2011 standard [32]).

Muffle tests (LENTON type ECF 12/10 equipment) were carried out to quantify AHPam and AHPus ash fractions, with reference to the ISO18122:2015 and 1016-104.4:1998 standard [33], according to the thermal program: (i) $8{ }^{\circ} \mathrm{C} \mathrm{min}^{-1}$ heating rate from room temperature up to $500{ }^{\circ} \mathrm{C}$ with $1 \mathrm{~h}$ dwell at $500{ }^{\circ} \mathrm{C}$; (ii) $8{ }^{\circ} \mathrm{C} \mathrm{min}-1$ heating rate from $500{ }^{\circ} \mathrm{C}$ up to $815{ }^{\circ} \mathrm{C}$ with $2 \mathrm{~h}$ dwell at $500^{\circ} \mathrm{C}$.

The elemental analyzer CHNS/O PerkinElmer 2400 Series-II was used to perform the ultimate analysis of AHPam and AHPus, obtaining mass percentages of $\mathrm{C}, \mathrm{H}, \mathrm{N}, \mathrm{S}$ and $\mathrm{O}$ on dry basis.

The AHPam and AHPus ashes, obtained from the abovementioned muffle treatment at $815^{\circ} \mathrm{C}$, were analyzed by $\mathrm{X}$-Ray Fluorescence $(\mathrm{XRF})$ to determine their semi-quantitative elemental composition. The XRF device was a Spectro Xepos I instrument, with wavelength dispersion method, equipped with a detector that does not allow detecting elements with atomic mass lower than that of magnesium $(\mathrm{Mg})$.

Inductively Coupled Plasma Atomic Emission Spectroscopy (ICP-AES) analyses were carried out with VARIAN 720 ES ICP-AES instrument in order to detect sodium (Na) in the AHPam material, a key element contained in the super-absorbent polymer of diapers (sodium polyacrylate) [34].

$\mathrm{XRF}$ and ICP-AES techniques are of interest, since the presence of $\mathrm{Na}$ and other mineral elements (e.g., $\mathrm{K}, \mathrm{Si}, \mathrm{Ca}, \mathrm{Na}, \mathrm{Mg}, \mathrm{Al}$ ) can lead to the formation of eutectics [35], which can in turn generate low-melting ashes at the temperatures of those processes investigated in this work; these melting species may be responsible for important process issues, as they can develop agglomerates in fluidized beds or obstructions by recondensation in colder areas $[36,37]$.

\subsection{Bed Material and Fluid-Dynamic Conditions for Devolatilization Tests}

The bed material used for devolatilization tests was sand; its physical properties of fluid-dynamic interest (range of particle diameter $d_{p}$ and particle density $\rho_{p}$ ) are summarized in Table 1. At experimental conditions of devolatilization tests (see Section 2.4), this sand belongs to Group B of generalized Geldart classification [38], for which minimum fluidization velocity coincides with minimum bubbling velocity, i.e., Group B materials cannot provide homogeneous fluidization. From here on, the term "minimum fluidization velocity $\left(u_{m f}\right)$ " is used to name the beginning of sand fluidization, which is for sure at bubbling regime. Values of $u_{m f}$ (Table 1$)$, used as references to set devolatilization experimental conditions in this work (see Section 2.4), were determined according to the method described by Di Giuliano et al. [36].

Table 1. Bed material: physical properties of fluid-dynamic interest and minimum fluidization velocity $\left(u_{m f}\right)$ as a function of temperature at devolatilization conditions described in Section 2.4.

\begin{tabular}{cc}
\hline Bed Material & Sand \\
\hline $\boldsymbol{d}_{p}(\mu \mathrm{m})$ & $212-250$ \\
$\rho_{p}\left(\mathbf{k g ~ m}^{-3}\right)$ & 2587 \\
\hline $\mathrm{T}\left({ }^{\circ} \mathbf{C}\right)$ & $\boldsymbol{u}_{\boldsymbol{m}}\left(\mathrm{cm} \mathrm{s}^{-\mathbf{1}}\right)$ \\
\hline 500 & 2.9 \\
600 & 2.7 \\
700 & 2.5 \\
800 & 2.3 \\
\hline
\end{tabular}




\subsection{Devolatilization Tests: Experimental Rig and Procedure}

Devolatilization tests were performed for both waste materials from AHP, introduced in Section 2.1 (AHPam and AHPus). Each material was investigated at four temperature levels (500, 600, 700, $800{ }^{\circ} \mathrm{C}$ ), with two fluidizing agents (pure $\mathrm{N}_{2}$ or air diluted by $\mathrm{N}_{2}$ to obtain 1.3-2.3 vol\% of $\mathrm{O}_{2}$ at the bed inlet). Devolatilizations with pure $\mathrm{N}_{2}$ may be considered as preparatory experiments for a pyrolysis process, while those with diluted air have the same role related to gasification.

The laboratory-scale plant for devolatilization tests is described in detail elsewhere [36]. For the sake of brevity and clarity, only basic information is given here about this experimental rig (Figure 2). It included (Figure 2) one fluidized bed quartz reactor $(5 \mathrm{~cm}$ internal diameter), heated by a cylindrical electric furnace, in turn controlled by a thermocouple submerged in the bed. The reactor was fed upward by the fluidizing agent, with its flow rate set to always develop 1.4 times $u_{m f}$ (Table 1 ) at chosen test conditions. The mass of sand in the reactor was selected to obtain $7.5 \mathrm{~cm}$ high beds (1.5 times the bed diameter).

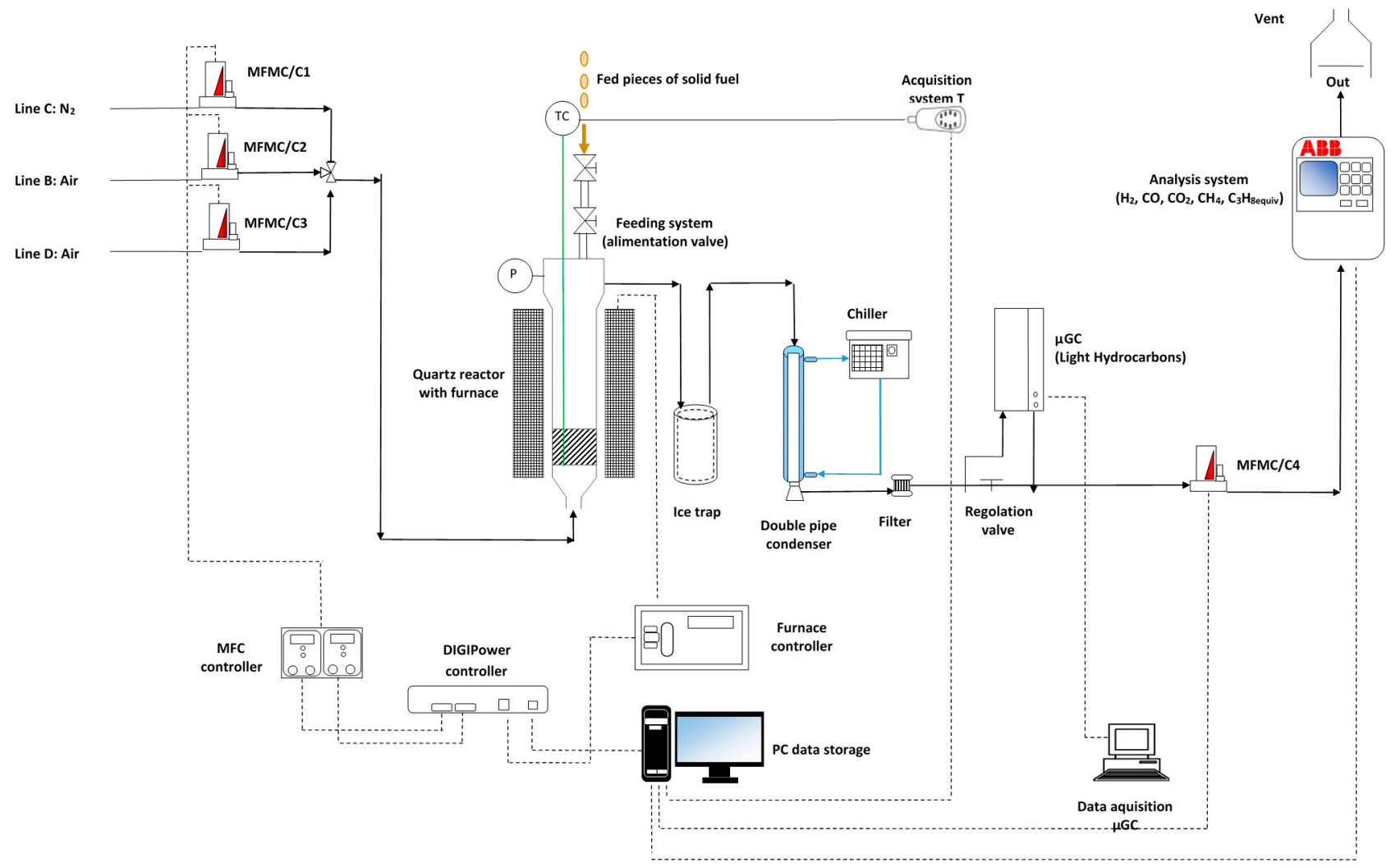

Figure 2. Schematic view of the laboratory-scale experimental apparatus for devolatilization tests.

Devolatilization products left the reactor from its top, together with the fluidizing agent which also served as a carrier; condensable species were separated by an ice trap and a double-pipe glass condenser at $0^{\circ} \mathrm{C}$. The composition of dry product gases was measured online by an ABB analysis system and a micro gas-chromatograph ( $\mu \mathrm{CG}$ ) AGILENT 490 (see [36] for further details). The ABB system measured the volume percentages of $\mathrm{CO}$, $\mathrm{CO}_{2}, \mathrm{CH}_{4}$ and $\mathrm{H}_{2}$, and the overall hydrocarbons content as $\mathrm{ppm}_{\mathrm{v}}$ of equivalent $\mathrm{C}_{3} \mathrm{H}_{8}$. The raw values of equivalent $\mathrm{C}_{3} \mathrm{H}_{8}$ measured by the $\mathrm{ABB}$ system included $\mathrm{CH}_{4}$ contribution; in this work, the quantity presented as "equivalent $\mathrm{C}_{3} \mathrm{H}_{8}$ " is intended as already reduced by the contribution of $\mathrm{CH}_{4}$. From here on, "equivalent $\mathrm{C}_{3} \mathrm{H}_{8}$ " means "hydrocarbons other than methane".

Due to the fluffy nature of raw waste materials from AHP (Figure 1), prior to devolatilization AHPam and AHPus were compacted in the form of circular tablets by means 
of a press; those circular tablets were then cut in half to obtain individual pieces small enough to be fed into the reactor (about $0.2-0.4 \mathrm{~g}$ per piece).

AHPam and AHPus pieces were fed individually by hand, thanks to a vertical double valve system at the top of the reactor (Figure 2, see [36] for further details). Each piece experienced an abrupt heating, from room temperature to the one of the fluidized bed, just in the small duration of piece falling. This fast temperature increase could not be performed by TGA equipment.

For each set of parameters "material kind/fluidizing agent/bed temperature", three individual waste pieces were devolatilized, constituting three repetitions of a given test condition. The thermal decomposition of each piece was carried out until completion, before feeding the following; therefore, the process could be considered as a semi-batch, intrinsically at unsteady state.

Outlet molar flow rates $\left(F_{i, \text { out }}\right.$, with $i=\mathrm{H}_{2}, \mathrm{CO}, \mathrm{CO}_{2}, \mathrm{CH}_{4}$ and equivalent $\left.\mathrm{C}_{3} \mathrm{H}_{8}\right)$ as functions of time $(t)$ were obtained from ABB measurements, thanks to the assumption of the $\mathrm{N}_{2}$ inlet flow rate as the internal standard. With regard to tests involving diluted air, it is reasonable to hypothesize that fed $\mathrm{O}_{2}$ was mostly converted and, in any case, it represented a negligible flow rate in comparison to the $\mathrm{N}_{2}$ one; therefore, fed $\mathrm{N}_{2}$ was always assumed as the internal standard. Once $F_{i, o u t}$, masses of fuel pieces $\left(m_{p}\right)$ and their compositions (see Section 3.1) were known, mole balances were performed. On the basis of these balances, for each devolatilization, integral-average values (" $a v^{\prime \prime}$ "superscript in Equations (1)-(3)) were calculated for the following quantities:

- $\quad$ Gas yield ( $\eta^{a v}$, Equation (1));

- $\quad$ Percentage of $i$ on dry and dilution free basis $\left(Y_{i}^{a v}\right.$, Equation (2));

- Carbon conversion $\left(\chi^{a v}{ }_{C}\right.$, Equation (3), with $n_{j}$ as the number of $C$ atoms in Ccontaining species $j$ ).

For those quantities defined in Equations (1)-(3), averages out of the three repetitions were calculated for each set "material kind/fluidizing agent/bed temperature", provided with related standard deviations.

$$
\begin{gathered}
\eta^{a v}=\frac{\sum_{i} \int F_{i, o u t} d t}{m_{p}} \\
\text { with } i=H_{2}, \mathrm{CO}, \mathrm{CO}_{2}, \mathrm{CH}_{4} \text { and equivalent } \mathrm{C}_{3} \mathrm{H}_{8} \\
Y_{i}^{a v}=\frac{\int F_{i, o u t} d t}{\sum_{i} \int F_{i, o u t} d t} 100 \\
\text { with } i=H_{2}, \mathrm{CO}, \mathrm{CO}_{2}, \mathrm{CH}_{4} \text { and equivalent } \mathrm{C}_{3} \mathrm{H}_{8} \\
\chi_{\mathrm{C}}^{a v}=\frac{(12 \mathrm{~g} \mathrm{~mol}-1) \times \sum_{j}\left(n_{j} \int F_{j, o u t} d t\right)}{m_{p}\left(\frac{100-\text { wot } \% \text { ar of moisture }}{100}\right)\left(\frac{\text { wot } \% \text { db of } \mathrm{C}}{100}\right)} 100 \\
\text { with } j=\mathrm{CO}, \mathrm{CO}_{2}, \mathrm{CH}_{4} \text { and equivalent } \mathrm{C}_{3} \mathrm{H}_{8}
\end{gathered}
$$

Cold gas efficiency ( $\xi$, Equation (4), with $L H V_{g, i}$ as the Lower Heating Value of gaseous species $i$ in the product gas, $L H V_{p}$ as Lower Heating Value of the solid fuel) was calculated as an additional overall evaluation parameter, out of the three repetitions for each set "material kind/fluidizing agent/bed temperature".

$$
\xi=\frac{\sum_{k}\left[\left(\sum_{i}\left(L H V_{g, i} \int F_{i, o u t} d t\right)\right)_{k} / m_{p, k}\right]}{3 \cdot L H V_{p}}
$$

with $i=\mathrm{H}_{2}, \mathrm{CO}, \mathrm{CO}_{2}, \mathrm{CH}_{4}$ and equivalent $\mathrm{C}_{3} \mathrm{H}_{8} ; k=$ repetitions $1,2,3$

Lower heating values in Equation (4) were found in the literature for the syngas components [39,40] and tested waste materials from AHP [34] (Table 2). 
Table 2. Lower heating values of gas components $\left(L H V_{g, i}\right)$ and waste materials from AHP $\left(L H V_{p}\right)$, defined for Equation (4).

\begin{tabular}{ccc}
\hline Gas & $\mathbf{L H V}_{\boldsymbol{g}, \boldsymbol{i}}\left[\mathbf{M} \mathbf{~ k m o l}^{\mathbf{- 1}}\right]$ & Ref \\
\hline $\mathrm{CO}$ & 282.99 & {$[39]$} \\
$\mathrm{CO}_{2}$ & 0 & {$[39]$} \\
$\mathrm{H}_{2}$ & 241.83 & {$[39]$} \\
$\mathrm{CH}_{4}$ & 802.34 & {$[40]$} \\
$\mathrm{C}_{3} \mathrm{H}_{8}$ & 46.2 & \\
\hline Material & $\mathbf{L H V}_{\boldsymbol{p}}\left[\mathbf{M} \mathbf{~ k g}^{-\mathbf{1}}\right]$ & {$[34]$} \\
\hline AHPam & 23.60 & {$[34]$} \\
AHPus & 10.36 &
\end{tabular}

\subsection{Characterization of the Fluidized Bed after Devolatilization Tests}

Some morphological and topological aspects were observed by microscopy techniques, namely: (i) Scanning Electron Microscopy (SEM) with Zeiss GeminiSEM 500 microscope equipped with Energy Dispersive X-ray Spectrometry (EDS) for elemental analyses; (ii) observation by means of a stereomicroscope Leica s8 Apo model.

Results of EDS analyses are mentioned in Section 3.3, but only related SEM micrographs are shown. Both microscopy techniques were exploited to study possible agglomeration or sintering phenomena in the fluidized bed, which can interfere with the fluidization quality by increasing the average diameter of bed particles, therefore affecting the performance of thermochemical conversion [39].

This characterization was carried out on the spent fluidized sand at the end of the devolatilization tests (see Section 2.3); the sampling of spent bed particles was performed in different zones: coarse agglomerates of the sand bed (Figure 3a), top of the sand bed (Figure $3 b$ ), bottom of the sand bed (Figure 3c), intermediate part of the sand bed (Figure 3d).

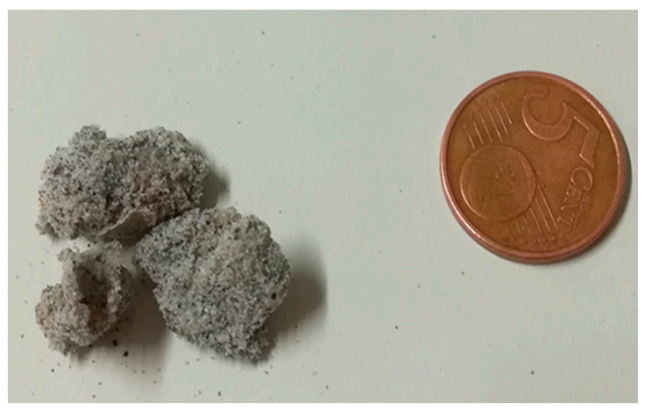

(a)

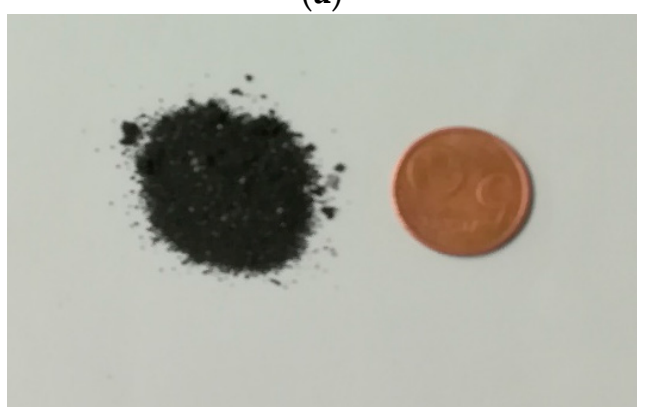

(c)

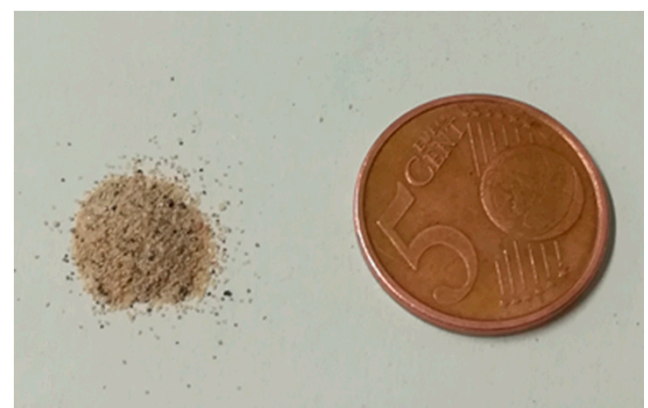

(b)

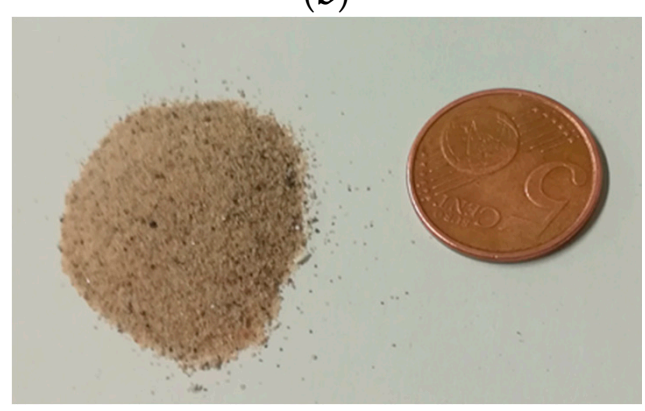

(d)

Figure 3. Examples of samples from the spent bed after the devolatilization tests: (a) coarse agglomerates of the bed, (b) top of the bed, (c) bottom of the bed, (d) intermediate part of the bed. 


\section{Results}

\subsection{Physical-Chemical Characterizations of AHPam and AHPus}

Table 3 shows the numerical results of proximate and ultimate analyses of AHPam and AHPus, obtained by TGA, oven tests, muffle tests, and the CHNS/O analyzer (see Section 2.2).

Table 3. Proximate and ultimate analyses of AHPam and AHPus ( $w t \%$ ar $=$ weight percent on as-received basis; $\mathrm{w} t \% \mathrm{db}=$ weight percent on dry basis).

\begin{tabular}{|c|c|c|}
\hline & \multicolumn{2}{|c|}{$w t \%$ ar } \\
\hline & AHPam & AHPus \\
\hline Dry weight & 94.2 & 93.4 \\
\hline Moisture & 5.8 & 6.6 \\
\hline Ashes & 7.5 & 10.7 \\
\hline Volatile matter & 82.8 & 81.5 \\
\hline \multirow[t]{2}{*}{ Fixed carbon } & 3.9 & 1.2 \\
\hline & \multicolumn{2}{|c|}{$w t \% d b$} \\
\hline $\mathrm{C}$ & 65.3 & 43.5 \\
\hline $\mathbf{H}$ & 10.3 & 6.6 \\
\hline $\mathbf{N}$ & 0.0 & 0.1 \\
\hline S & 1.1 & 1.8 \\
\hline $\mathrm{O}$ & 23.3 & 48.0 \\
\hline
\end{tabular}

Table 4 summarizes the semi-quantitative elemental compositions of AHPam and AHPus, measured by XRF (see Section 2.2).

Table 4. Semi-quantitative elemental composition of AHPam and AHPus, measured by X-ray fluorescence $(\mathrm{XRF})$ (abs. err. = absolute error).

\begin{tabular}{ccccc}
\hline \multirow{2}{*}{ Element } & \multicolumn{2}{c}{ AHPam } & \multicolumn{2}{c}{ AHPus } \\
\cline { 2 - 5 } & $\mathbf{( w t} \%)$ & abs. err. (wt \%) & $\mathbf{( w t ~ \% )}$ & abs. err. (wt \%) \\
\hline $\mathbf{M g}$ & 1.007 & 0.031 & $<0.0020$ & 0.0 \\
$\mathbf{A l}$ & $<0.0020$ & 0.0 & $<0.0020$ & 0.0 \\
$\mathbf{S i}$ & 0.1016 & 0.0024 & 1.272 & 0.008 \\
$\mathbf{P}$ & 0.0581 & 0.001 & 0.5238 & 0.0034 \\
$\mathbf{S}$ & 0.03947 & 0.00049 & 4.467 & 0.005 \\
$\mathbf{C l}$ & 0.0079 & 0.00016 & 1.425 & 0.002 \\
$\mathbf{K}$ & 0.04641 & 0.00069 & 2.935 & 0.003 \\
$\mathbf{C a}$ & 11.99 & 0.01 & 1.157 & 0.002 \\
$\mathbf{T i}$ & 1.402 & 0.001 & 0.08108 & 0.00029 \\
$\mathbf{V}$ & 0.05397 & 0.0006 & 0.00465 & 0.00013 \\
$\mathbf{C r}$ & $<0.00010$ & 0.0 & 0.00796 & 0.00006 \\
$\mathbf{M n}$ & 0.01207 & 0.00008 & 0.00906 & 0.00007 \\
$\mathbf{F e}$ & 0.3068 & 0.0009 & 0.2159 & 0.0006 \\
\hline
\end{tabular}

Table 5 summarizes temperatures at which oxidative decomposition phenomena were no longer detectable during combustions in TGA equipment, for both AHPam and AHPus.

Table 5. End decomposition temperature of AHPam and AHPus, measured during TGA combustions under air flux.

\begin{tabular}{lccc}
\hline Heating Rates $\left({ }^{\circ} \mathbf{C} \mathbf{m i n}^{-1}\right)$ & 5 & 10 & 20 \\
\hline Temperature of decomposition end for AHPam $\left({ }^{\circ} \mathbf{C}\right)$ & 690 & 660 & 540 \\
Temperature of decomposition end for AHPus $\left({ }^{\circ} \mathbf{C}\right)$ & 530 & 520 & 540 \\
\hline
\end{tabular}




\subsection{Devolatilization Tests}

Figures 4 and 5 show four examples of devolatilizations at $800{ }^{\circ} \mathrm{C}$, one for each combination "fluidizing agent/material kind". As already noted by Di Giuliano et al. [36] about similar experiments with biomass pellets, the gaseous products $\left(\mathrm{H}_{2}, \mathrm{CO}, \mathrm{CO}_{2}, \mathrm{CH}_{4}\right.$, equivalent $\mathrm{C}_{3} \mathrm{H}_{8}$ hydrocarbons) were released by an unsteady state process, as evidenced by the characteristic asymmetric shape of $F_{i, \text { out }}(t)$ peaks. The numerical integration of $F_{i, \text { out }}$ $(t)$ curves with respect to time $(t)$ allowed the calculation of integral-average parameters defined by Equations (1)-(3) (see Section 2.4); these values were then averaged out of the three repetitions of pellet devolatilizations for each set of condition "material kind/fluidizing agent/bed temperature". In addition, cold gas efficiencies (Equation (4)) were calculated on the basis of abovementioned numerical integrations.

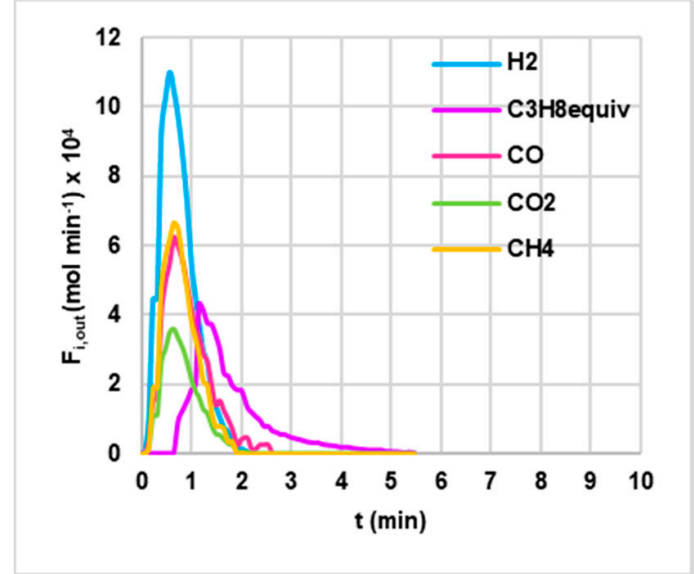

(a)

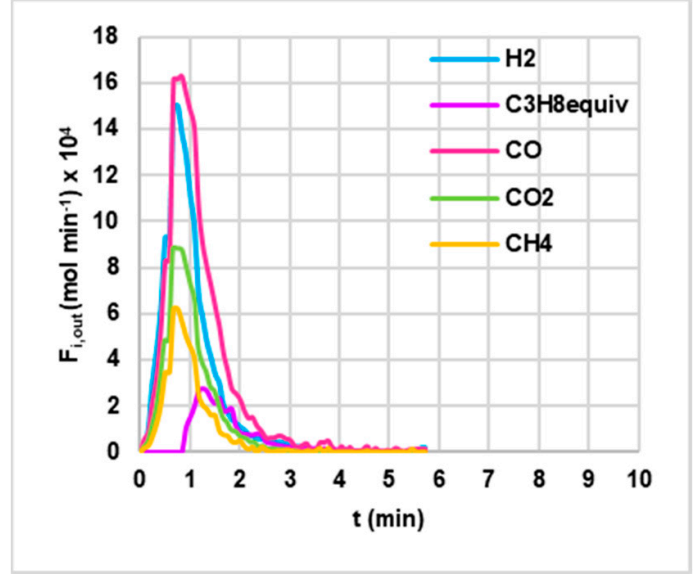

(b)

Figure 4. Example of $\mathrm{H}_{2}, \mathrm{CO}, \mathrm{CO}_{2}, \mathrm{CH}_{4}$ and equivalent $\mathrm{C}_{3} \mathrm{H}_{8}$ outlet molar flow rates $\left(\mathrm{F}_{\mathrm{i} \text {,out }}\right)$ as functions of time ( $\left.\mathrm{t}\right)$, produced by devolatilizations of AHPam (a) and AHPus (b), in the sand fluidized bed, at $800^{\circ} \mathrm{C}$, under nitrogen atmosphere.

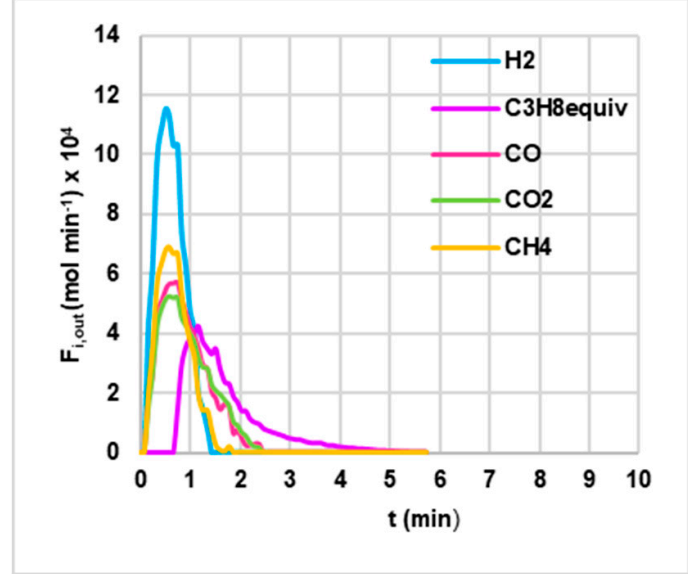

(a)

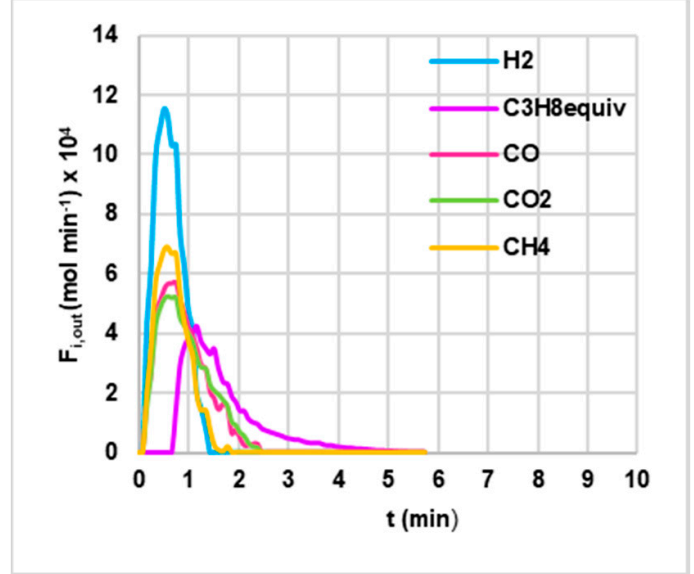

(b)

Figure 5. Example of $\mathrm{H}_{2}, \mathrm{CO}, \mathrm{CO}_{2}, \mathrm{CH}_{4}$ and equivalent $\mathrm{C}_{3} \mathrm{H}_{8}$ outlet molar flow rates $\left(\mathrm{F}_{\mathrm{i}, \text { out }}\right)$ as functions of time ( $\mathrm{t}$ ) produced by devolatilizations of AHPam (a) and AHPus (b), in the sand fluidized bed, at $800{ }^{\circ} \mathrm{C}$, under nitrogen plus air atmosphere (diluted air).

Bar charts were used to summarize the devolatilization performances of AHP materials under pure nitrogen (Figure 6) or diluted air (Figure 7), in terms of syngas composition $Y_{i}^{a v}$ (Equation (2), Figures $6 \mathrm{a}, \mathrm{b}$ and $7 \mathrm{a}, \mathrm{b}$ ), carbon conversion $\chi^{a v}{ }_{C}$ (Equation (3), Figures $6 c, d$ and $7 c, d$ ), and gas yield $\eta^{a v}$ (Equation (1), Figures $6 e, f$ and $\left.7 e, f\right)$. In both figures, the left column concerns AHPam, while the right one concerns AHPus. 


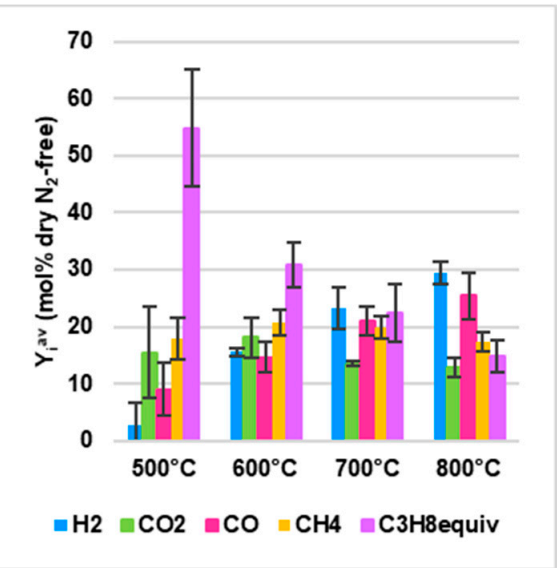

(a)

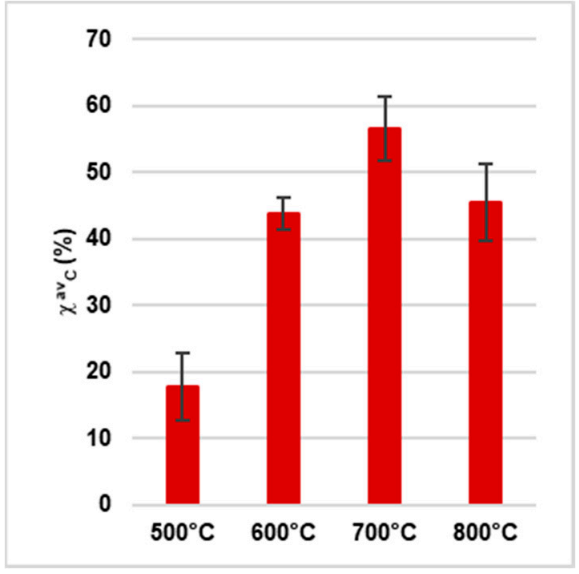

(c)

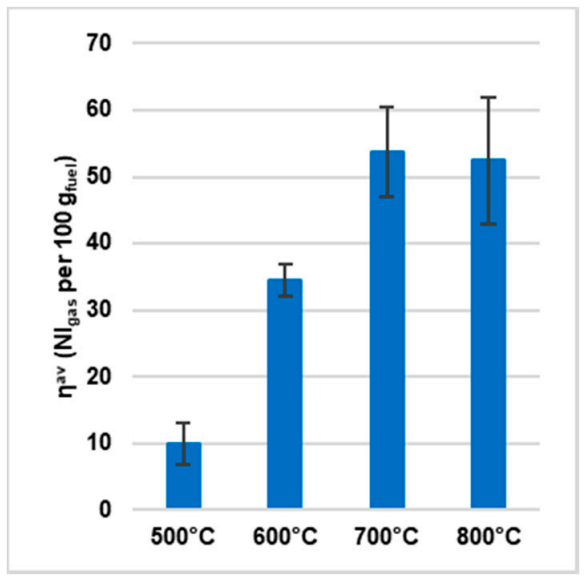

(e)

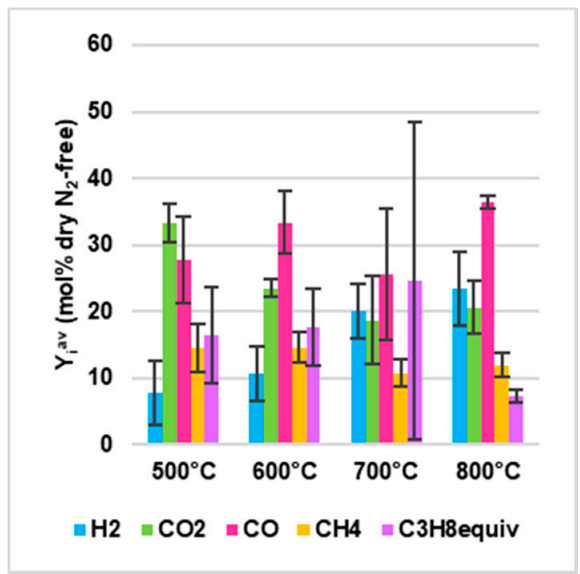

(b)

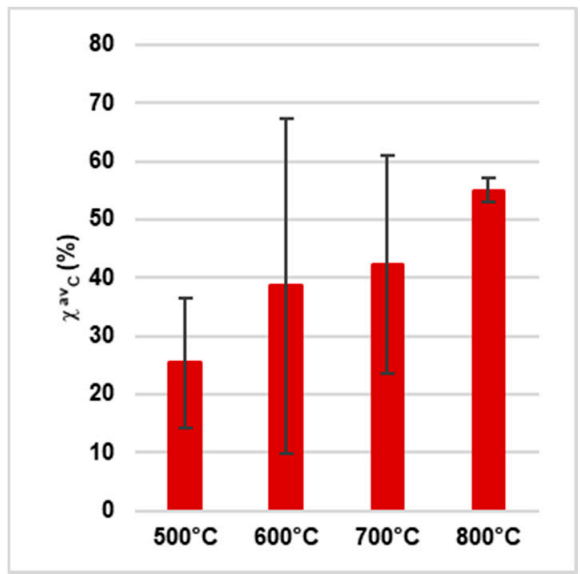

(d)

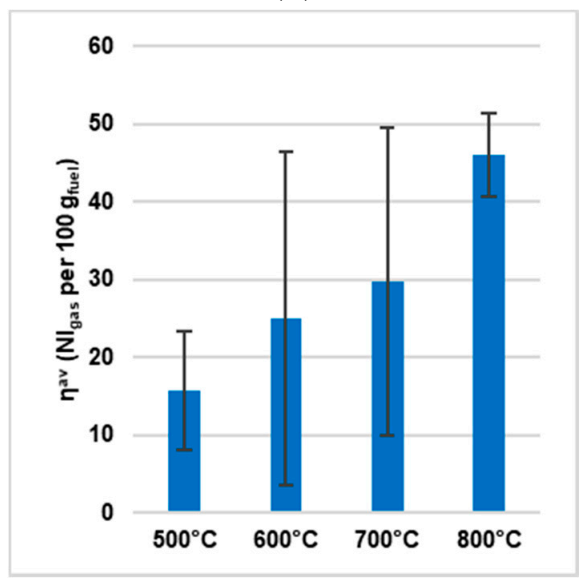

(f)

Figure 6. Experimental results of devolatilization tests under nitrogen atmosphere, in the sand fluidized bed, as functions of temperature: integral-average mol\% dry, dilution-free $\left(Y_{i}^{a v}\right.$, Equation (2)) of AHPam (a) AHPus (b); integral-average carbon conversion $\left(\chi^{a v}\right.$, Equation (3)) of AHPam (c) AHPus (d); integral-average gas yield ( $\eta^{a v}$, Equation (1)) of AHPam (e) AHPus (f); colored bars represent average values out of the three repetitions for each set "material kind/fluidizing agent/bed temperature", errors bars quantify the related standard deviations. 


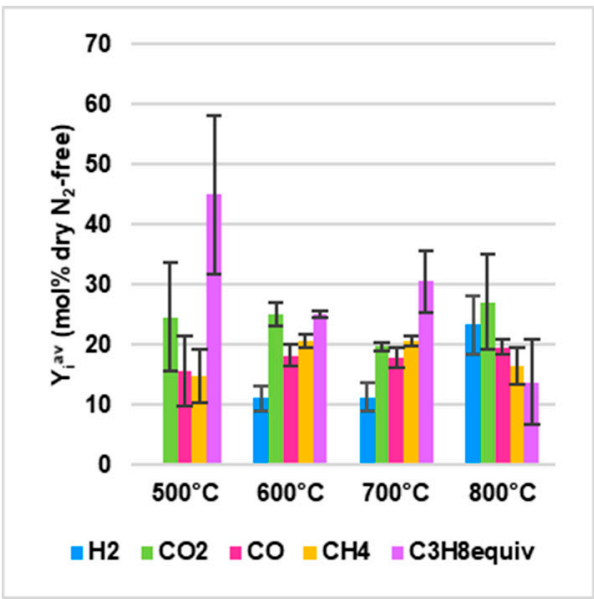

(a)

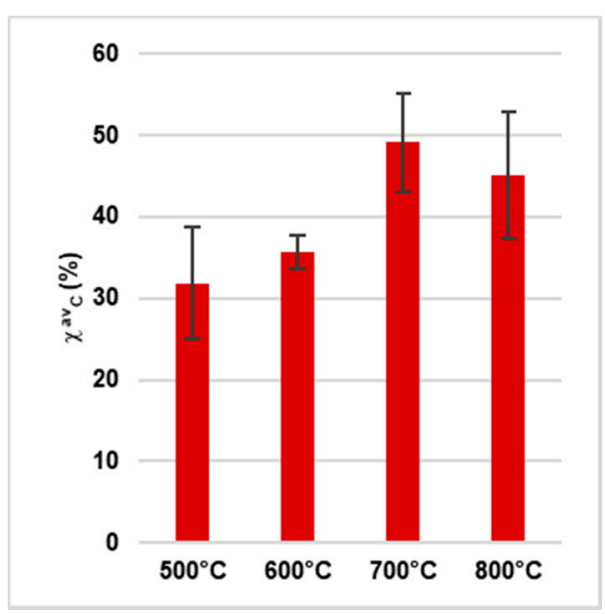

(c)

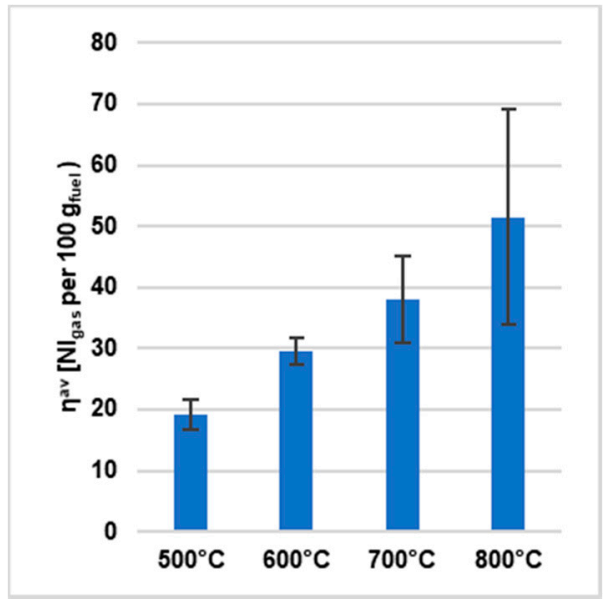

(e)

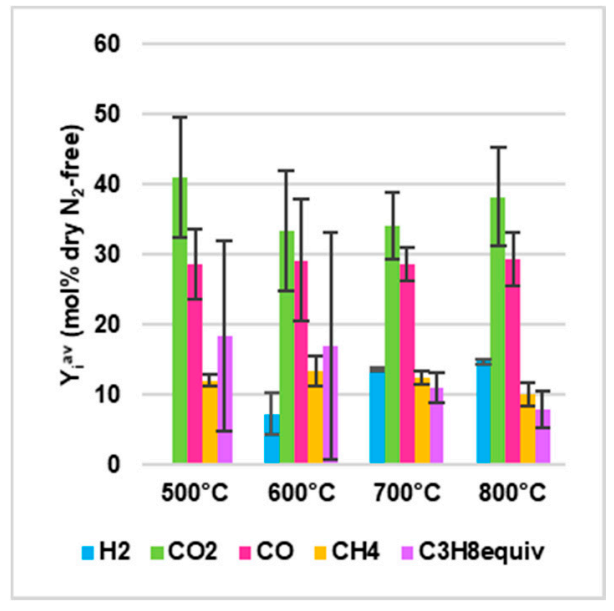

(b)

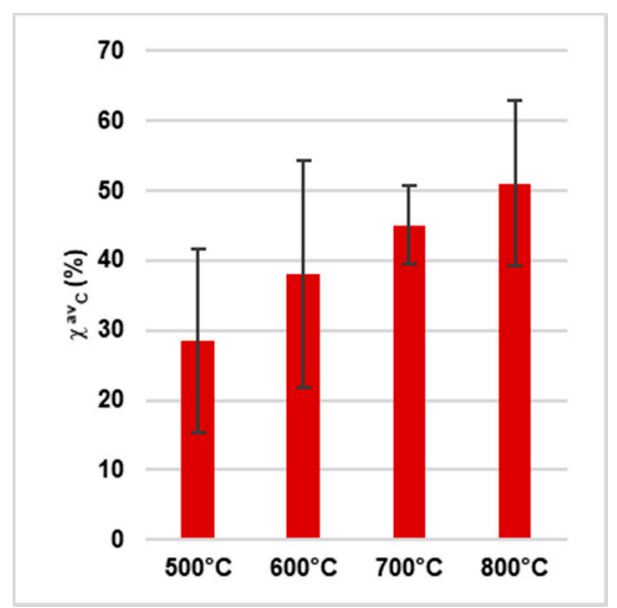

(d)

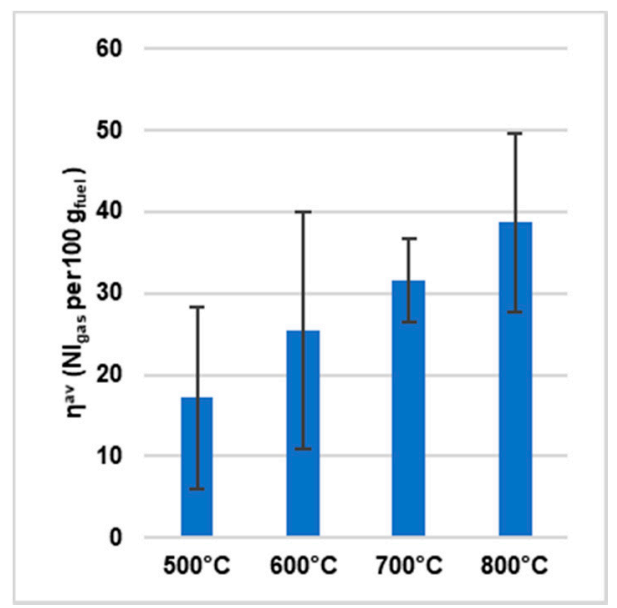

(f)

Figure 7. Experimental results of devolatilization tests under nitrogen plus air atmosphere, in the sand fluidized bed, as functions of temperature: integral-average mol\% dry, dilution-free $\left(Y_{i}^{a v}\right.$, Equation (2)) of AHPam (a) AHPus (b); integral-average carbon conversion $\left(\chi^{a v}{ }_{C}\right.$, Equation (3)) of AHPam (c) AHPus (d); integral-average gas yield ( $\eta^{a v}$, Equation (1)) of AHPam (e) AHPus (f); colored bars represent average values out of the three repetitions for each set "material kind/fluidizing agent/bed temperature", errors bars quantify the related standard deviations. 
Colored bars in Figures 6 and 7 represent average values out of the three repetitions for each set "material kind/fluidizing agent/bed temperature"; errors bars quantify the related standard deviations.

Numerical data showed in Figures 6 and 7 are detailed in Appendix A of this work.

Table 6 summarizes numerical values of cold gas efficiency $(\xi$, Equation (4)), calculated for each set "material kind/fluidizing agent/bed temperature", as described in Section 2.4.

Table 6. Cold gas efficiency ( $\xi$, Equation (4)) for each set "material kind/fluidizing agent/bed temperature".

\begin{tabular}{ccccc}
\hline $\mathbf{T}$ & \multicolumn{2}{c}{ Tests with $\mathbf{N}_{\mathbf{2}}$} & \multicolumn{2}{c}{ Tests with $\mathbf{N}_{\mathbf{2}}$ Plus Air } \\
\hline$\left({ }^{\circ} \mathbf{C}\right)$ & $\begin{array}{c}\text { AHPam } \\
(\mathbf{\%})\end{array}$ & $\begin{array}{c}\text { AHPus } \\
(\mathbf{\%})\end{array}$ & $\begin{array}{c}\text { AHPam } \\
(\mathbf{\%})\end{array}$ & $\begin{array}{c}\text { AHPus } \\
(\mathbf{\%})\end{array}$ \\
\hline 500 & 2.6 & 16.5 & 6.8 & 13.8 \\
600 & 27.6 & 27.1 & 14.3 & 23.9 \\
700 & 29.1 & 32.2 & 18.6 & 29.7 \\
800 & 28.8 & 51.6 & 23.8 & 33.1 \\
\hline
\end{tabular}

\subsection{Characterizations of Spent Fluidized Bed}

After devolatilization tests ended, the spent bed material was recovered and sampled by the procedure described in Section 2.5. Figure 8 shows pictures taken by the stereomicroscope on coarse sand agglomerates (Figure 3a). Figures 9-12 show SEM micrographs of different samples from the spent bed; more in detail, these picture reveal morphological and topological aspects of coarse agglomerates (Figure 9), bed bottom (Figure 10), bed intermediate zone (Figure 11) and bed top (Figure 12).

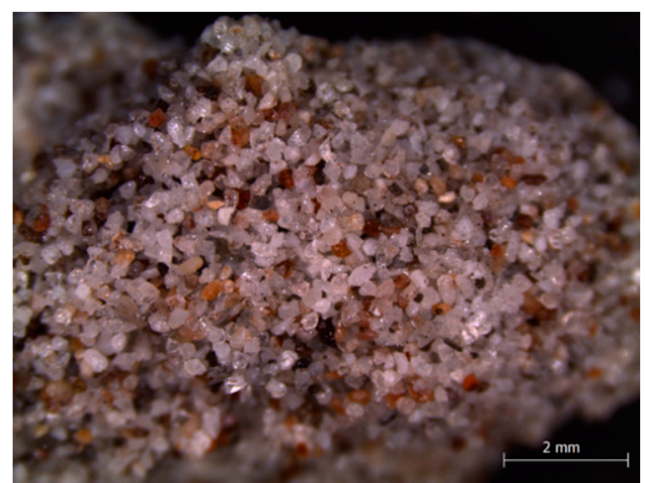

(a)

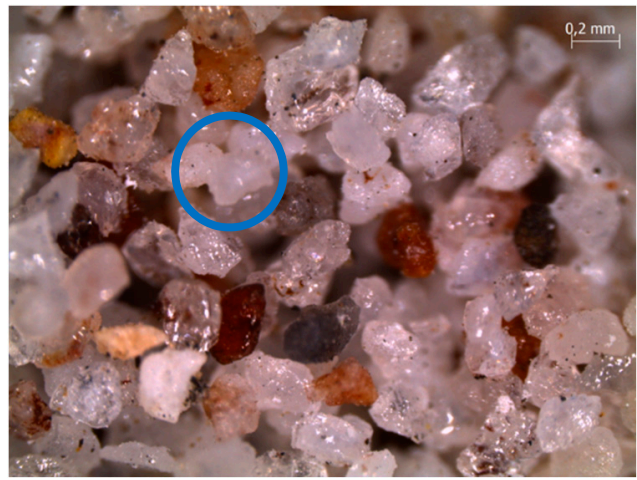

(c)

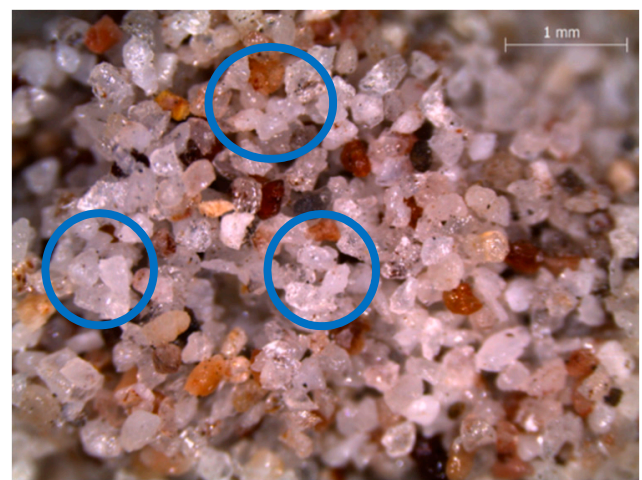

(b)

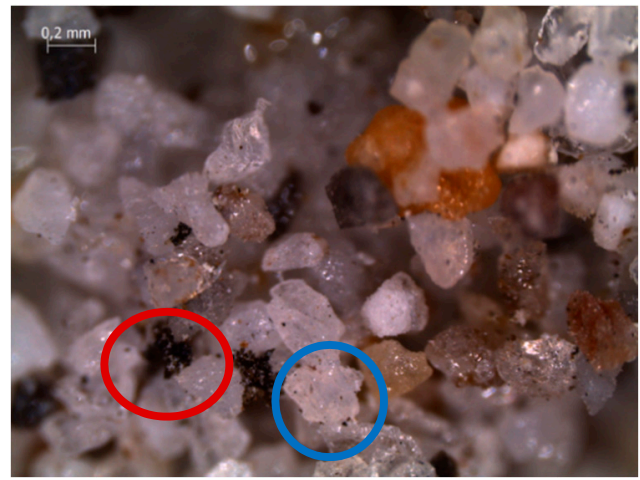

(d)

Figure 8. Stereo-microscope images of agglomerates from the spent sand bed after the last test, magnified at: $1 \times(\mathbf{a}) ; 2 \times($ b $) ; 4 \times(\mathbf{c}) ; 4 \times(\mathbf{d})$. 


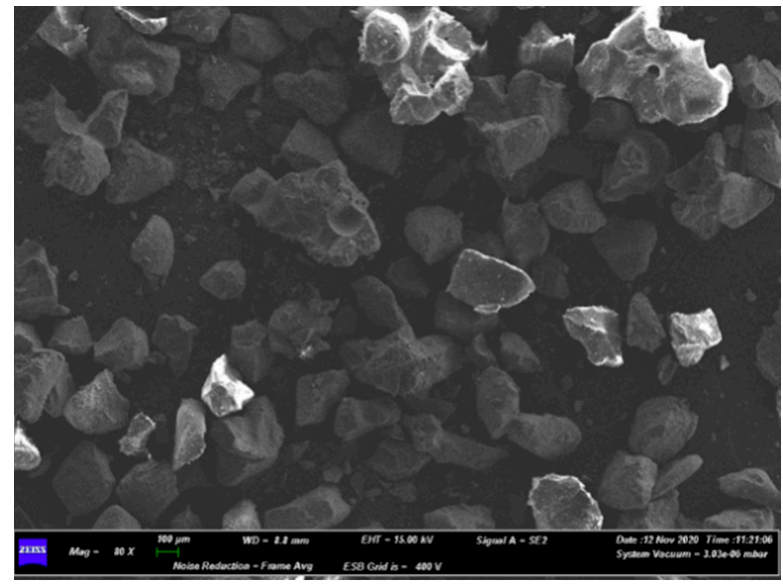

(a)

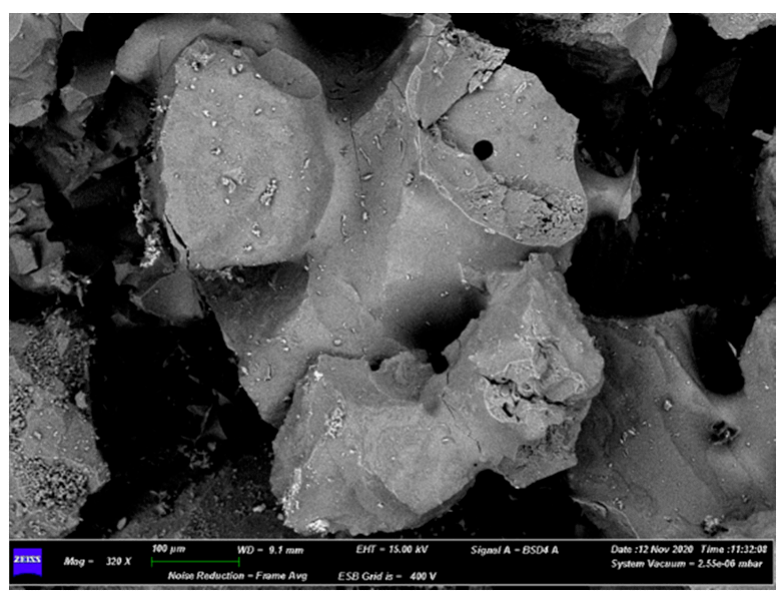

(b)

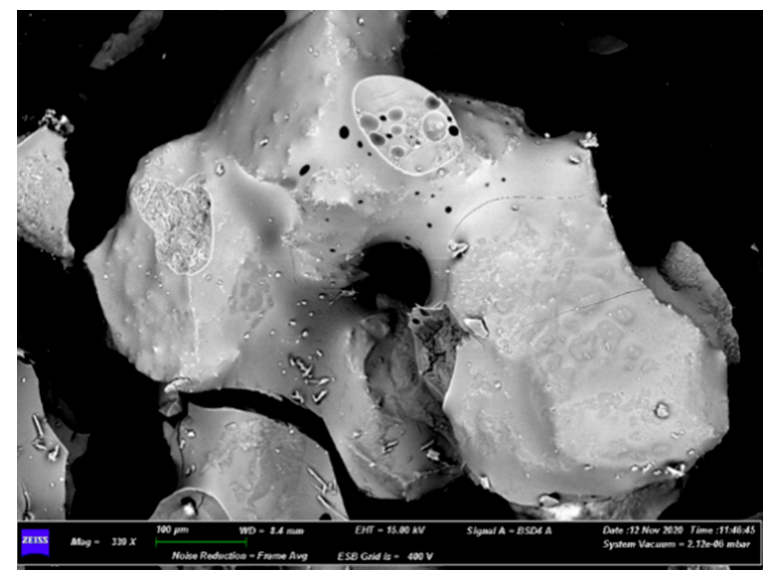

(c)

Figure 9. SEM micrographs of the coarse agglomerates from the spent sand bed after the last test, magnified at: $80 \times(\mathbf{a})$; $320 \times(\mathbf{b}) ; 339 \times(\mathbf{c})$.

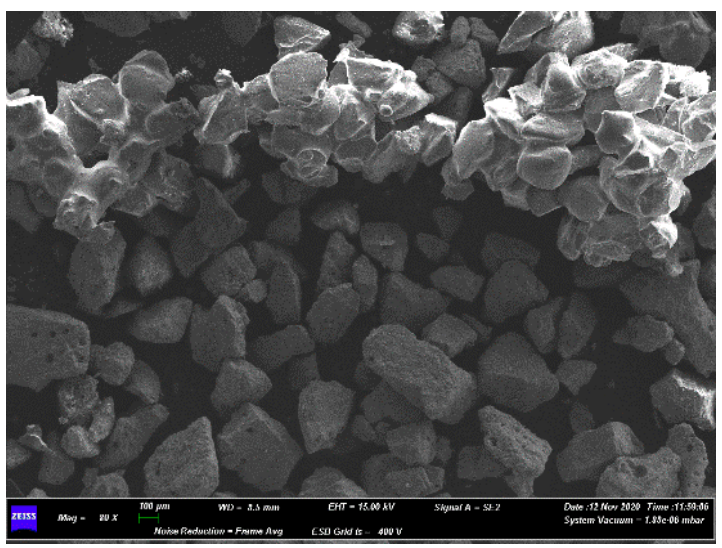

(a)

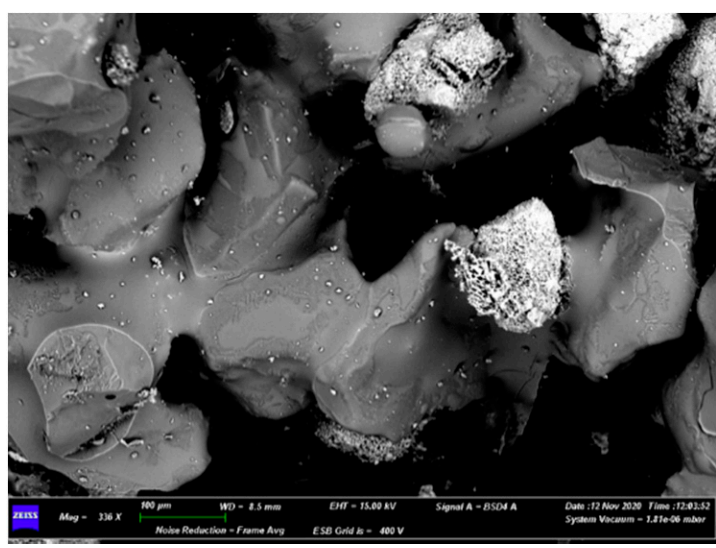

(b)

Figure 10. SEM micrographs of bottom of spent sand bed after the last test, magnified at: $80 \times(\mathbf{a}) ; 336 \times(\mathbf{b})$. 


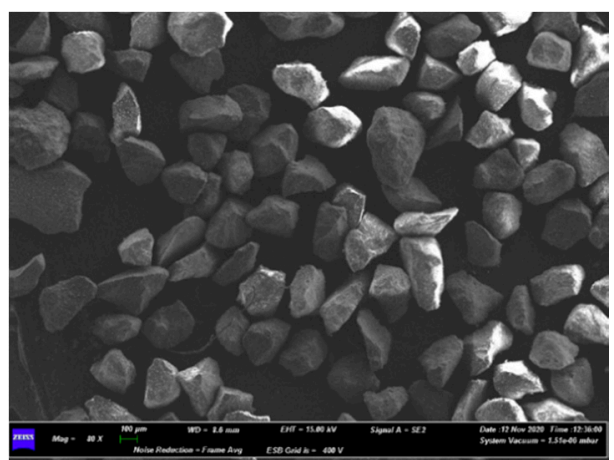

(a)

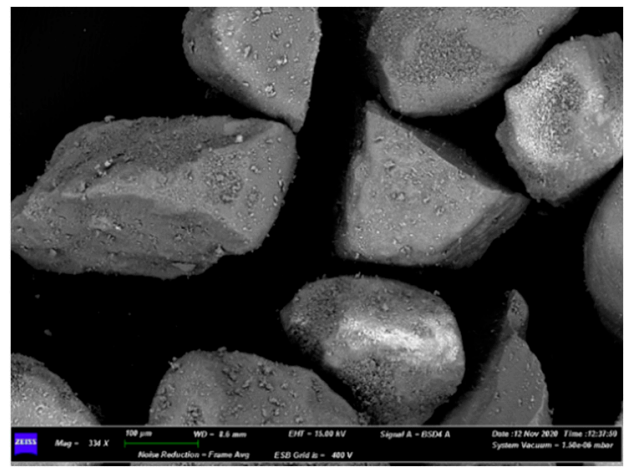

(b)

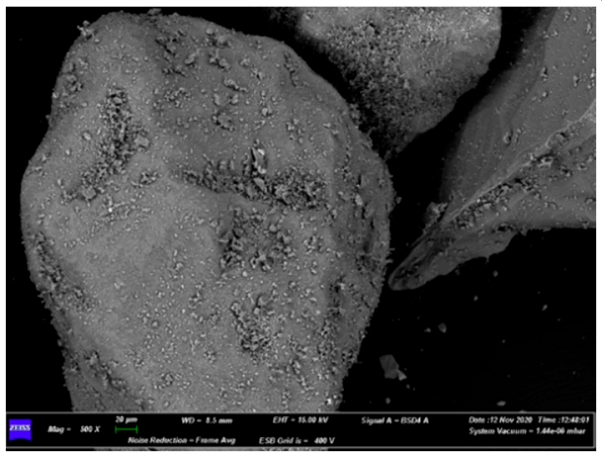

(c)

Figure 11. SEM micrographs of intermediate part of spent sand bed after the last test, magnified at: $80 \times(\mathbf{a}) ; 336 \times(\mathbf{b}) ; 500 \times(\mathbf{c})$.

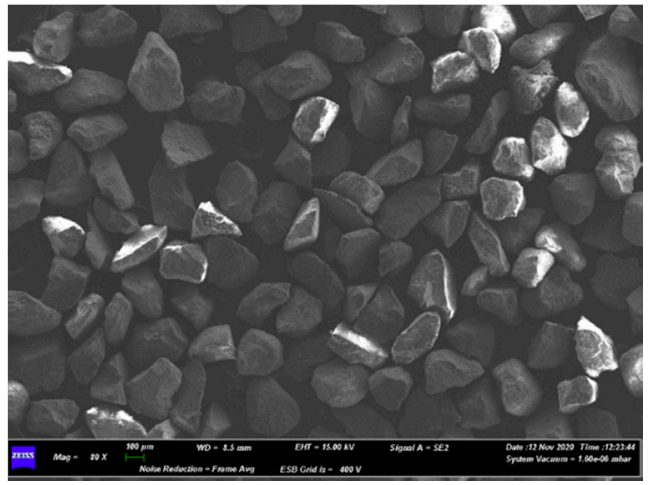

(a)

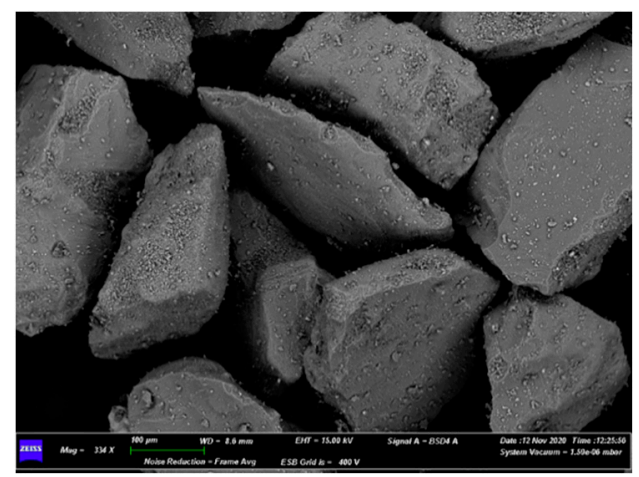

(b)

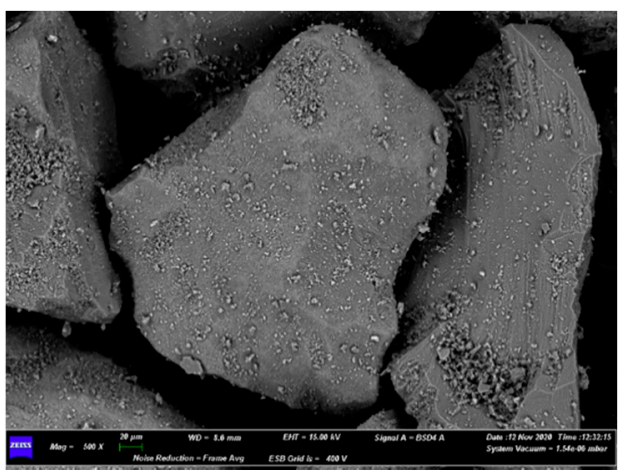

(c)

Figure 12. SEM micrographs of top of spent sand bed after the last test, magnified at: $80 \times(a)$; $334 \times(\mathbf{b}) ; 500 \times(\mathbf{c})$. 


\section{Discussion}

\subsection{Physical-Chemical Characterizations}

Table 3 shows results from proximate and ultimate analyses of AHPam and AHPus. A high volatile content resulted from proximate analyses of both materials $(82.8 \mathrm{wt} \%$ ar for AHPam and $81.5 \mathrm{wt} \%$ ar for AHPus), as well as an important ash fraction (12.5 wt $\%$ for AHPam and $11.4 \mathrm{wt} \%$ for AHPus), for instance, higher than that of SRF [19]. The high content of volatiles was considered to be a positive factor, since the conversion of these species is favored in the thermochemical processes considered in this work [39]. The ultimate analysis highlighted the absence of nitrogen or its presence in traces $(0.0 \mathrm{wt} \%$ $\mathrm{db}$ in AHPam and $0.1 \mathrm{wt} \% \mathrm{db}$ in AHPus, Table 3): this could be an interesting feature in an oxyfuel conversion, as it may allow expecting no development of nitrogen-based pollutants. In general, the ultimate analysis (Table 3) for AHPam and AHPus makes them appropriate for thermochemical processes.

The semi-quantitative elemental composition, measured by XRF (Table 4), identified the main elements in the ashes of AHPam and AHPus. Ashes from AHPam mainly contained $\mathrm{Mn}, \mathrm{Ca}$ and $\mathrm{Ti}$, while in ashes from AHPus there were mainly $\mathrm{Si}, \mathrm{P}, \mathrm{K}, \mathrm{Cl}$, and $\mathrm{Ca}$. With regard to $\mathrm{S}$, a not negligible quantity was found in AHPus, higher by one order of magnitude than $S$ in AHPam.

ICP-AES analyses indicated that Na content in AHPam was in the range of 2-3 wt\%; it is reasonable to assume a similar Na content in AHPus.

The Na-Si phase diagram [35] shows the formation of an eutectic in the range of temperature $500-800{ }^{\circ} \mathrm{C}$, corresponding to $45 \mathrm{wt} \%$ of $\mathrm{Na}$ in $\mathrm{Si}$. This range of temperature is exactly the same considered in devolatilizations of this work. Even though only $2-3 \mathrm{wt} \%$ of $\mathrm{Na}$ was detected or assumed in waste materials from AHP, this value could have become locally higher, therefore triggering the agglomeration of sand particles. This phenomenon was demonstrated by SEM-EDS analyses of bed samples after devolatilization tests (see Section 3.2, Figures 8-10).

\subsection{Experimental Data from Devolatilization Tests}

With regard to devolatilization tests, it is worth to stress again that they were carried out with two fluidizing agents: pure $\mathrm{N}_{2}$ or $\mathrm{N}_{2}$ plus air (i.e., diluted air). Tests with pure $\mathrm{N}_{2}$ represented a preliminary experimentation which simulated the pyrolysis of waste materials from AHP, while those with diluted air did the same for the gasification process [30]. In addition, and more interestingly for the purposes of this work, tests with pure $\mathrm{N}_{2}$ served as a reference to evaluate effects due to the slightly oxidizing atmosphere of experiments with diluted air.

The chosen devolatilization temperatures matched well with results from the combustion tests performed in TGA (Table 5), which highlighted how the combustion process ended in a range of temperatures between 500 and $600{ }^{\circ} \mathrm{C}$. From the analysis of these results at $20^{\circ} \mathrm{C} \mathrm{min}^{-1}$ (the fastest heating rate performed in TGA, Table 5), decomposition by combustion extinguished at $540^{\circ} \mathrm{C}$ for both AHPam and AHPus; considering that devolatilization tests involved a definitively more abrupt temperature increase from room to $500,600,700$ or $800{ }^{\circ} \mathrm{C}$ and that thermal decomposition phenomena tend to overlap as the heating rate is increased, it is reasonable to assume that conditions in the laboratory-scale fluidized bed were sufficient to induce a substantial thermal decomposition of AHP-derived fuels.

The results from devolatilizations were presented in Section 3.2. With both fluidizing agents and both AHPam and AHPus, some general effects emerged due to the temperature increase, which were quantified by means of the parameters defined in Section 2.4.

Integral-average gas yield ( $\eta^{a v}$, Equation (1)) for AHPam had maximum values (net of standard deviations) at $700-800{ }^{\circ} \mathrm{C}$ in $\mathrm{N}_{2}$ atmosphere (Figure 6e) and at $800{ }^{\circ} \mathrm{C}$ in $\mathrm{N}_{2}$ plus air atmosphere (Figure 7e), while $\eta^{a v}$ always increased as the temperature was increased for AHPus with both fluidizing agents, reaching maximum values at $800{ }^{\circ} \mathrm{C}$ (Figures $6 \mathrm{f}$ and $7 \mathrm{f}$ ). 
Carbon conversion $\left(\chi^{a v}{ }_{C}\right.$, Equation (3)) for AHPam had its maximum value at $700{ }^{\circ} \mathrm{C}$ with both fluidizing agents (Figures $6 \mathrm{c}$ and $7 \mathrm{c}$ ); for AHPus, an increasing trend was observed as the temperature was increased, with the highest values at $800{ }^{\circ} \mathrm{C}$, even though there were important standard deviations at 600 and $700{ }^{\circ} \mathrm{C}$ for AHPus in diluted air (Figures $6 \mathrm{~d}$ and $7 \mathrm{~d}$ ). These observations highlighted a significant differentiation of behaviors due to the solid fuel nature: with AHPam, it is not needed to heat a fluidized bed up to $800{ }^{\circ} \mathrm{C}$ to obtain the maximum $\chi^{a v} \mathrm{C}$.

As for integral-average gas compositions $\left(Y_{i}^{a v}\right.$, Equation (2), Figures 6a,b and 7a,b), generally the temperature increase involved an increase in $\mathrm{H}_{2}$ percentage and a decrease in hydrocarbons fraction (equivalen $\mathrm{C}_{3} \mathrm{H}_{8}$ ), with the variations of their two $Y^{a v}{ }_{i}$ appearing in reciprocal correlation; it is sensible to hypothesize that hydrogen atoms which were converted in gaseous $\mathrm{H}_{2}$ came from the cellulosic and plastic matrix of the AHP materials [34].

Differences emerged concerning the formation of gaseous hydrocarbons, when comparing the gas developed from the two materials: under both atmospheres, the decomposition of AHPam produced a syngas with higher equivalent $\mathrm{C}_{3} \mathrm{H}_{8}$ fraction (Figure $6 \mathrm{a}$ vs. Figure $6 \mathrm{~b}$, Figure $7 \mathrm{a}$ vs. Figure $7 \mathrm{~b}$ ). This difference was exalted at $500{ }^{\circ} \mathrm{C}$, the lowest

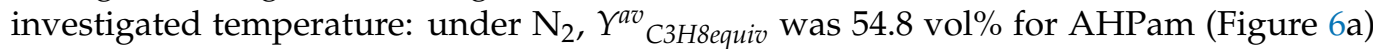
and $16.5 \mathrm{vol} \%$ for AHPus (Figure $6 \mathrm{~b}$ ) on dry and dilution-free basis; the same trends and orders of magnitude were observed in the $\mathrm{N}_{2}$ plus air case (Figure $7 \mathrm{a}$ vs. Figure $7 \mathrm{~b}$ ). This aspect could be correlated to the composition of the material, since the AHPam contained higher carbon and hydrogen fractions than those of AHPus (elemental analyses, Table 3). This effect, due to the nature of waste materials from AHP, decreased as the temperature was increased.

A deeper qualitative insight about hydrocarbons' nature came from the $\mu C G$ analyses. Peaks with retention times compatible with those of ethylene/acetylene and propene were often detected at all tested temperatures, while those of benzene were occasionally found in syngas from tests at $800{ }^{\circ} \mathrm{C}$ under diluted air. In any case-as evidenced by Di Giuliano et al. for similar tests on the same rig of this work - those $\mu \mathrm{GC}$ analyses are only an optional means to identify some of the hydrocarbons quantified by the ABB system as "equivalent $\mathrm{C}_{3} \mathrm{H}_{8}$ "; it must be taken into account that the $\mu \mathrm{CG}$ sampling was manually started and occurred on a flow produced by an unsteady process [36].

As for oxidized carbon in gases $\left(\mathrm{CO}\right.$ and $\left.\mathrm{CO}_{2}\right)$, it is reasonable to assume that oxygen could come only from the solid phases in tests under pure $\mathrm{N}_{2}$, while fed $\mathrm{O}_{2}$ acted as an additional source in tests with $\mathrm{N}_{2}$ plus air. This assumption found confirmation in the experimental results: for both waste materials and all temperatures, devolatilizations under diluted air produced syngas with higher fractions of $\mathrm{CO}$ and $\mathrm{CO}_{2}$ (Figure $7 \mathrm{a}, \mathrm{b}$ ), in comparison with those obtained from devolatilizations under pure $\mathrm{N}_{2}$ (Figure 6a,b). On the other hand, under both atmospheres, AHPus developed higher fractions of $\mathrm{CO}$ and $\mathrm{CO}_{2}$ (Figures $6 \mathrm{~b}$ and $7 \mathrm{~b}$ ) than those obtained from AHPam (Figures 6a and 7a), in agreement with the oxygen content of the two solid fuels (Table 3). The non-linear behavior of $\mathrm{CO}_{2}$ concentration with respect to temperature could be ascribed to the network of exothermic and endothermic reactions and the competitive trend of their thermodynamic and kinetic peculiarities.

Numerical data represented in Figures 6 and 7 are reported in Appendix A of this work (Tables A1 and A2): sometimes, important standard deviations were observed. This variability was ascribed to: (i) the macroscopic inhomogeneity of the AHP materials, which made it difficult to obtain solid pressed tablets which were fully representative of the average composition of each whole solid bulk inventory; (ii) the low density of the analyzed materials, together with small allowed dimensions of pressed tablets, involved small absolute masses of fed solid fuel per each devolatilization test, then implying a more significant relative weight of the inherent experimental errors on determined quantities.

The cold gas efficiency ( $\xi$, Equation (4), Table 6) was used as an overall parameter to better evaluate and compare the experimental devolatilization performances. The results 
in Table 6 confirmed that the temperature increase produced positive effects, since it made the $\xi$ grow for both materials and both atmospheres in the range $500-800{ }^{\circ} \mathrm{C}$. At a given temperature, AHPus devolatilizations under both atmospheres resulted in higher $\xi$ values than those related to AHPam (with the minor exception for pure $\mathrm{N}_{2}$ at $600{ }^{\circ} \mathrm{C}$, Table 6). The highest $\xi$ occurred for AHPus, at $800{ }^{\circ} \mathrm{C}$ : $56.5 \%$ in $\mathrm{N}_{2}$ atmosphere and $33.1 \%$ in $\mathrm{N}_{2}$ plus air atmosphere, respectively (Table 6). This evidence was corroborated by the higher volatile content in AHPus samples (Table 3). These results are in further agreement with the detected improvements of the composition of the produced gas (Figures $6 a, b$ and $7 a, b)$, i.e., an increase in gaseous compounds with a higher calorific value $\left(\mathrm{H}_{2}, \mathrm{CO}\right.$ and $\left.\mathrm{CH}_{4}\right)$ as the temperature was increased, with the concomitant increase in gas yield $\eta^{a v}$. This suggested that the endothermic reactions of devolatilization were favored as the temperature was increased, and that the light hydrocarbon compounds, collectively reported as equivalent $\mathrm{C}_{3} \mathrm{H}_{8}$, were widely decomposed at $800^{\circ} \mathrm{C}$.

Overall, among all tested conditions, the range $700-800{ }^{\circ} \mathrm{C}$ appears as the best for the thermal decomposition of both waste materials from AHP, with the best performances in terms of cold gas efficiencies achieved with AHPus at $800{ }^{\circ} \mathrm{C}$.

As a side note, the experimenters of this work would like to underline that important and progressive deposition of allegedly carbonaceous species occurred on the reactor walls and inside downstream pipelines. This made it impossible and unrealistic to close carbon balances; as a first approximation, it can be assumed that the share $\left(100-\chi^{a v} \mathrm{C}\right)$ is attributable to these deposits. This is also a significative issue, which must be considered in hypothetical scaled-up processes of the thermochemical conversion of waste materials from AHP.

\subsection{Characterization of Spent Fluidized Bed}

The SEM-EDS and stereoscopic microscope analyses allowed us to deepen the insight about the agglomeration of ashes and bed particles during the devolatilization tests (see Section 2.5).

Figure 8 shows pictures taken by the stereomicroscope on coarse sand agglomerates, shown at 1:1 scale in Figure 3a. Figure $8 \mathrm{a}$ is an overall view of bed particles after the whole devolatilization campaign under $\mathrm{N}_{2}$ and air atmosphere: many sand particles in the diameter range of $212-250 \mu \mathrm{m}$ (Table 1) appeared as stuck in a very compact block, i.e., agglomerated into coarse groups in the order of 1-2 cm. This phenomenon could negatively affect the fluidization quality of the bed. Magnifications of stereomicroscope pictures (Figure $8 b-d$ ) evidenced the occurrence of Si particles fusion (blue circles) and carbon deposition (red circle).

Figures 9-12 show SEM micrographs of the spent sand bed after the last test; more in detail, these pictures revealed morphological and topological aspects of coarse agglomerates (Figure 9), bed bottom (Figure 10), bed intermediate zone (Figure 11) and bed top (Figure 12).

Figure 9a shows irregularly shaped particles (dark grey) and some agglomerates (light grey, top right). Those agglomerates were detailed by Figure 9b,c, which shows: smooth bridges and jagged areas characterized by crusts and holes, together with melted covers adhering to the original grains. EDS microanalyses highlighted the presence of Si as the main constituent of those bridges, with a lower amount of $\mathrm{Na}$ and traces of other elements such as $\mathrm{Al}, \mathrm{Mg}, \mathrm{K}$ and $\mathrm{Fe}$, documented elsewhere as possible causes of sintering phenomena [41].

In its upper part, Figure 10a shows a relatively huge chain of agglomerates, quite evident by contrast with the smaller, well segregated particles below. Figure $10 \mathrm{~b}$ evidences the presence of the same kind of smooth bridges already found in Figure $9 b, c$, and areas covered by melted layers (brighter zone in Figure 10b), mainly containing Si, Na and traces of $\mathrm{K}, \mathrm{Al}$ and $\mathrm{Ca}$, according to EDS analyses. In addition, EDS determined that the lightest zone in Figure 10b consists of a porous structure mainly made up of Ca. 
Intermediate (Figure 11) and top (Figure 12) zones of the bed revealed a very similar morphology, also at the single-particle level, as can be seen by magnified micrographs in Figures 11c and 12c. A superficial, spread deposition of fine particles was observed (Figures $11 b, c$ and $12 b, c)$, but no sintering occurred on the whole. SEM-EDS results confirmed that the spread fine particles were made up of $\mathrm{Si}$ and traces of $\mathrm{Al}, \mathrm{Mg}, \mathrm{Na}, \mathrm{K}$ and $\mathrm{Ca}$. zation:

Overall, the following observations could be inferred from this microscopic characteri-

1. A priori, it was expected to find a greater number of melted particles/agglomerates in the upper part of the bed, because it is the zone of the first contact between its free surface and the falling pieces of waste materials from AHP; however, the exact opposite was found, as the smaller particles had moved to the top of the bed, while the larger ones, allegedly formed on the top, were found on the bottom. This is proof of the good mixing within the fluidized bed;

2. Agglomerations did not diffusely involve the whole bed inventory. This suggested that only where the bed had experienced locally high Na concentrations the eutectic had formed [35], even though the quantity of $\mathrm{Na}$ in the fed fuel was low $(2-3 \mathrm{wt} \%)$ compared to Na eutectic concentration in Si (45 wt\%) [35].

\section{Conclusions}

This work dealt with devolatilizations of two kinds of waste generated from $\mathrm{Ab}$ sorbent Hygiene Products (AHP): shredded scraps of as-manufactured diapers (AHPam) and shredded cellulosic fraction of used and sterilized diapers (AHPus). Tests were carried out in a laboratory-scale bubbling fluidized bed made of sand, at temperatures between $500{ }^{\circ} \mathrm{C}$ and $800^{\circ} \mathrm{C}$, under inert and mildly oxidizing atmospheres. This experimental campaign served as a preparatory step for possible scaling-up of thermochemical conversion processes with waste materials from AHP as the solid fuel feedstock.

Devolatilization performances were evaluated in terms of gas yield, carbon conversion and cold gas efficiency.

Temperature in the range $500-800^{\circ} \mathrm{C}$ appeared as the most influential process parameter, followed by the oxygen content in the fluidization agent and the nature of solid fuel. Devolatilization tests performed at 700 and $800{ }^{\circ} \mathrm{C}$, using pure nitrogen as the fluidizing agent, allowed us to obtain the highest values of gas yield (53.7 Nl $100 \mathrm{~g}_{\text {fuel }}{ }^{-1}$ for AHPam at $700{ }^{\circ} \mathrm{C} ; 46.0 \mathrm{Nl} 100 \mathrm{~g}_{\text {fuel }}{ }^{-1}$ for AHPus at $\left.800{ }^{\circ} \mathrm{C}\right)$, carbon conversion $(56.5 \%$ for AHPam at $700{ }^{\circ} \mathrm{C} ; 55.0 \%$ for AHPus at $\left.800{ }^{\circ} \mathrm{C}\right)$, and cold gas efficiency $(28.8 \%$ for AHPam, $51.6 \%$ for AHPus both at $800^{\circ} \mathrm{C}$ ).

The oxidative atmosphere determined poorer performances in terms of cold gas efficiency (e.g., at $800{ }^{\circ} \mathrm{C}, 23.8 \%$ for AHPam and 33.1\% for AHPus), sensibly because of the more pronounced oxidation of gaseous products, leading to a reduction in the lower heating value of syngas.

According to cold gas efficiency, AHPus appeared as the more interesting fuel feedstock when the main aim of thermochemical conversion is the production of power and heat.

SEM-EDS analyses evidenced the occurrence of agglomeration and sintering of the bed particles, ascribed to low-melting elements in the fuel ashes, such as $\mathrm{Na}, \mathrm{Ca}$, Si and K. Nevertheless, this phenomenon did not spread within the whole bed inventory and the bed mixing was kept during devolatilizations.

Important depositions of allegedly carbonaceous species were noted inside the reactor and on internal walls of downstream pipelines.

The presented experimental investigation provided results and useful information concerning the behavior of waste materials from AHP in thermochemical conversions occurring in fluidized beds. Technical issues, such as sand particle agglomeration and dirt depositions, were documented in view of the possible scale-up of thermochemical conversion processes of waste materials from AHP. In addition, devolatilization experimental 
results were made available for possible model validations in further studies, which could also be used to investigate process economics at hypothetical industrial scales.

Overall, AHP waste appeared as an interesting feedstock for thermochemical processes, especially if aimed at power/heat production.

Author Contributions: Conceptualization, K.G. and A.D.G.; methodology, K.G. and A.D.G.; software A.D.G. and B.M.; validation, K.G. and A.D.G.; formal analysis, K.G. and A.D.G.; investigation, K.G., A.D.G. and B.M.; resources, K.G.; data curation, K.G., A.D.G. and B.M.; writing-original draft preparation, B.M.; writing-review and editing, K.G., A.D.G. and B.M.; visualization, K.G., A.D.G. and B.M.; supervision, K.G.; project administration, K.G.; funding acquisition, K.G. All authors have read and agreed to the published version of the manuscript.

Funding: This research was funded by ALMACIS s.r.l.

Institutional Review Board Statement: Not applicable.

Informed Consent Statement: Not applicable.

Data Availability Statement: The data presented in this study are available on request from the corresponding author.

Acknowledgments: The provision of AHP materials by ALMACIS s.r.l. is acknowledged. The authors warmly thank Giampaolo Antonelli for his technical support, and Fabiola Ferrante for XRF and $\mathrm{CHNS} / \mathrm{O}$ analyses and management.

Conflicts of Interest: The authors declare no conflict of interest. The funders had no role in the design of the study; in the collection, analyses, or interpretation of data; in the writing of the manuscript, or in the decision to publish the results.

\section{Appendix A}

This appendix summarizes the numerical results discussed in this manuscript. Tables A1 and A2 show the experimental data of devolatilization tests, discussed in the main text and reported as bar charts in Figures 6 and 7.

Table A1. Experimental results of devolatilization tests under nitrogen atmosphere, as functions of temperature (av3: average of results from the three individual pellets; sd3: standard deviation of results from the three individual pellets).

\begin{tabular}{|c|c|c|c|c|c|c|c|c|c|c|c|c|c|c|}
\hline \multirow[t]{3}{*}{ Sample } & \multirow{2}{*}{\multicolumn{2}{|c|}{$\begin{array}{c}\eta^{a v} \\
(\mathrm{Nl} \text { Per } \\
\left.100 \mathrm{~g}_{\text {fuel }}\right)\end{array}$}} & \multirow{2}{*}{\multicolumn{2}{|c|}{$\frac{\chi^{a v} c}{(\%)}$}} & \multirow{2}{*}{\multicolumn{2}{|c|}{$\begin{array}{c}Y^{a v}{ }^{a} 2 \\
\text { (mol\% Dry } \\
\mathrm{N}_{2} \text {-Free) }\end{array}$}} & \multirow{2}{*}{\multicolumn{2}{|c|}{$\begin{array}{c}Y^{a v} \text { C3H8equiv } \\
\text { (mol\% Dry } \\
\mathrm{N}_{2} \text {-Free) }\end{array}$}} & \multirow{2}{*}{\multicolumn{2}{|c|}{$\begin{array}{c}Y^{a v} \mathrm{CO} \\
\text { (mol\% Dry } \\
\mathrm{N}_{2} \text {-Free) }\end{array}$}} & \multirow{2}{*}{\multicolumn{2}{|c|}{$\begin{array}{c}\mathrm{Y}^{a v} \mathrm{CO} 2 \\
\text { (mol\% Dry } \\
\mathrm{N}_{2} \text {-Free) }\end{array}$}} & \multirow{2}{*}{\multicolumn{2}{|c|}{$\begin{array}{c}\mathrm{Y}^{a v} \mathrm{CH} 4 \\
\text { (mol\% Dry } \\
\mathrm{N}_{2} \text {-Free) }\end{array}$}} \\
\hline & & & & & & & & & & & & & & \\
\hline & av3 & sd3 & av3 & sd3 & av3 & sd3 & av3 & $\mathrm{sd} 3$ & av3 & sd3 & av3 & $\mathrm{sd} 3$ & av3 & sd3 \\
\hline \multicolumn{15}{|c|}{$500^{\circ} \mathrm{C}$} \\
\hline AHPam & 10.0 & 3.11 & 17.8 & 5.1 & 2.80 & 3.90 & 54.8 & 10.2 & 9.00 & 4.62 & 15.5 & 7.91 & 17.8 & 3.63 \\
\hline AHPus & 15.8 & 7.67 & 25.4 & 11.1 & 7.90 & 4.80 & 16.5 & 7.26 & 27.8 & 6.50 & 33.3 & 3.00 & 14.5 & 9.96 \\
\hline \multicolumn{15}{|c|}{$600^{\circ} \mathrm{C}$} \\
\hline AHPam & 34.5 & 2.43 & 43.8 & 2.5 & 15.6 & 0.63 & 30.8 & 3.96 & 14.7 & 2.71 & 18.1 & 3.50 & 20.8 & 2.24 \\
\hline AHPus & 25.0 & 21.4 & 38.6 & 28.7 & 10.7 & 4.07 & 17.7 & 5.86 & 33.4 & 4.66 & 23.5 & 1.40 & 14.7 & 0.38 \\
\hline \multicolumn{15}{|c|}{$700^{\circ} \mathrm{C}$} \\
\hline AHPam & 53.7 & 6.66 & 56.5 & 4.9 & 23.3 & 3.72 & 22.5 & 5.03 & 21.0 & 2.55 & 13.5 & 0.38 & 19.8 & 2.02 \\
\hline AHPus & 29.8 & 19.8 & 42.2 & 18.7 & 20.1 & 4.07 & 24.7 & 23.8 & 25.7 & 9.79 & 18.7 & 6.62 & 10.8 & 4.00 \\
\hline \multicolumn{15}{|c|}{$800^{\circ} \mathrm{C}$} \\
\hline AHPam & 52.5 & 9.51 & 45.5 & 5.8 & 29.5 & 2.05 & 14.8 & 2.80 & 25.4 & 4.04 & 12.9 & 1.74 & 17.5 & 1.73 \\
\hline AHPus & 46.0 & 5.40 & 55.0 & 2.1 & 23.5 & 5.53 & 7.40 & 0.98 & 36.4 & 0.89 & 20.7 & 3.95 & 12.0 & 1.36 \\
\hline
\end{tabular}


Table A2. Experimental results of devolatilization tests under nitrogen plus air atmosphere, as functions of temperature (av3: average of results from the three individual pellets; sd3: standard deviation of results from the three individual pellets).

\begin{tabular}{|c|c|c|c|c|c|c|c|c|c|c|c|c|c|c|}
\hline \multirow[t]{3}{*}{ Sample } & \multirow{2}{*}{\multicolumn{2}{|c|}{$\begin{array}{c}\eta^{a v} \\
(\mathrm{Nl} \text { Per } \\
\left.100 \mathrm{~g}_{\text {fuel }}\right)\end{array}$}} & \multirow{2}{*}{\multicolumn{2}{|c|}{$\frac{\chi^{a v} c}{(\%)}$}} & \multirow{2}{*}{\multicolumn{2}{|c|}{$\begin{array}{c}\mathrm{Y}^{a v} \mathrm{H}_{2} \\
\text { (mol\% Dry } \\
\mathrm{N}_{2} \text {-Free) }\end{array}$}} & \multirow{2}{*}{\multicolumn{2}{|c|}{$\begin{array}{c}Y^{a v} \text { C3H8equiv } \\
\text { (mol\% Dry } \\
\mathrm{N}_{2} \text {-Free) }\end{array}$}} & \multirow{2}{*}{\multicolumn{2}{|c|}{$\begin{array}{c}Y^{a v} \mathrm{cO} \\
\text { (mol\% Dry } \\
\mathrm{N}_{2} \text {-Free) }\end{array}$}} & \multirow{2}{*}{\multicolumn{2}{|c|}{$\begin{array}{c}\mathrm{Y}^{a v} \mathrm{CO} 2 \\
\text { (mol\% Dry } \\
\mathrm{N}_{2} \text {-Free) }\end{array}$}} & \multirow{2}{*}{\multicolumn{2}{|c|}{$\begin{array}{c}\mathrm{Y}^{a v} \mathrm{CH} 4 \\
\text { (mol\% Dry } \\
\mathrm{N}_{2} \text {-Free) }\end{array}$}} \\
\hline & & & & & & & & & & & & & & \\
\hline & av3 & sd3 & av3 & sd3 & av3 & sd3 & av3 & sd3 & av3 & $\mathrm{sd} 3$ & av3 & sd3 & av3 & sd3 \\
\hline \multicolumn{15}{|c|}{$500^{\circ} \mathrm{C}$} \\
\hline AHPam & 19.2 & 2.53 & 31.9 & 6.9 & 0.00 & 0.00 & 45.0 & 13.3 & 15.7 & 5.90 & 24.6 & 9.00 & 14.8 & 4.40 \\
\hline AHPus & 17.2 & 11.2 & 28.4 & 13.2 & 0.00 & 0.00 & 18.4 & 13.6 & 28.6 & 5.00 & 41.0 & 8.50 & 12.0 & 0.80 \\
\hline \multicolumn{15}{|c|}{$600^{\circ} \mathrm{C}$} \\
\hline AHPam & 29.6 & 2.14 & 35.7 & 2.00 & 11.1 & 2.1 & 25.0 & 0.60 & 18.2 & 1.90 & 25.0 & 2.10 & 20.6 & 1.20 \\
\hline AHPus & 25.5 & 14.6 & 38.0 & 16.3 & 7.3 & 3.3 & 16.9 & 16.2 & 29.1 & 8.70 & 33.4 & 8.60 & 13.3 & 2.10 \\
\hline \multicolumn{15}{|c|}{$700^{\circ} \mathrm{C}$} \\
\hline AHPam & 38.0 & 7.11 & 49.1 & 6.00 & 11.3 & 2.30 & 30.5 & 5.03 & 17.9 & 1.70 & 19.7 & 0.60 & 30.5 & 0.80 \\
\hline AHPus & 31.6 & 5.14 & 45.1 & 5.50 & 13.6 & 0.30 & 11.1 & 2.20 & 28.6 & 2.50 & 34.2 & 4.80 & 11.1 & 1.00 \\
\hline \multicolumn{15}{|c|}{$800^{\circ} \mathrm{C}$} \\
\hline AHPam & 51.5 & 17.6 & 45.1 & 7.90 & 23.3 & 5.00 & 13.8 & 7.10 & 19.6 & 1.20 & 27.0 & 7.90 & 16.3 & 3.10 \\
\hline AHPus & 38.7 & 10.9 & 51.1 & 11.8 & 14.7 & 0.40 & 7.80 & 2.60 & 29.3 & 3.80 & 38.2 & 7.10 & 10.0 & 1.70 \\
\hline
\end{tabular}

\section{References}

1. Perea-Moreno, M.A.; Samerón-Manzano, E.; Perea-Moreno, A.J. Biomass as renewable energy: Worldwide research trends. Sustainability 2019, 11, 863. [CrossRef]

2. Bongaarts, J. Development: Slow down population growth. Nature 2016, 530, 409-412. [CrossRef] [PubMed]

3. Ellen MacArthur Foundation Circular Economy-UK, USA, Europe, Asia \& South America-The Ellen MacArthur Foundation. Available online: https:/ /www.ellenmacarthurfoundation.org/ (accessed on 23 March 2021).

4. The World Bank What a Waste: An Updated Look into the Future of Solid Waste Management. Available online: https://www.worldbank.org/en/news/immersive-story/2018/09/20/what-a-waste-an-updated-look-into-the-futureof-solid-waste-management (accessed on 11 March 2021).

5. EC European Commission-Environment-Circular Economy Strategy. Available online: http://ec.europa.eu/environment/ circular-economy/index_en.htm (accessed on 11 March 2021).

6. Obama, B. The irreversible momentum of clean energy: Private-sector efforts help drive decoupling of emissions and economic growth. Science 2017, 355, 126-129. [CrossRef] [PubMed]

7. Marris, E. Why young climate activists have captured the world's attention. Nature 2019, 573, 471-473. Available online: https:/ / www.nature.com/articles/d41586-019-02696-0 (accessed on 11 March 2021). [CrossRef] [PubMed]

8. United Nations Climate Change The Paris Agreement I UNFCCC. Available online: https:/ /unfccc.int/process-and-meetings / the-paris-agreement/the-paris-agreement (accessed on 11 March 2021).

9. COP 24 I UNFCCC. Available online: https://unfccc.int/process-and-meetings/conferences/past-conferences/katowice-climatechange-conference-december-2018/sessions-of-negotiating-bodies/cop-24 (accessed on 11 March 2021).

10. A European Green Deal I European Commission. Available online: https: / / ec.europa.eu/info/strategy / priorities-2019-2024 / european-green-deal_en (accessed on 3 January 2021).

11. Johnston, R.B. Arsenic and the 2030 Agenda for sustainable development. Arsen. Res. and Glob. Sustain. As 2016, 12-14. [CrossRef]

12. Arena, U. Process and technological aspects of municipal solid waste gasification. A review. Waste Manag. 2012, 32, 625-639. [CrossRef] [PubMed]

13. Lombardi, L.; Carnevale, E.; Corti, A. A review of technologies and performances of thermal treatment systems for energy recovery from waste. Waste Manag. 2015, 37, 26-44. [CrossRef] [PubMed]

14. Materazzi, M.; Foscolo, P.U. The role of waste and renewable gas to decarbonize the energy sector. In Substitute Natural Gas from Waste: Technical Assessment and Industrial Applications of Biochemical and Thermochemical Processes; Academic Press: London, UK, 2019; ISBN 9780128155547.

15. Lig2Liq-Cost Effective Conversion of Lignite and Waste to Liquid Fuels. Available online: https://www.lig2liq.eu/ (accessed on 3 January 2021).

16. Weber, G.; Di Giuliano, A.; Rauch, R.; Hofbauer, H. Developing a simulation model for a mixed alcohol synthesis reactor and validation of experimental data in IPSEpro. Fuel Process. Technol. 2016, 141, 167-176. [CrossRef] 
17. Rapagnà, S.; Gallucci, K.; Foscolo, P.U. Olivine, dolomite and ceramic filters in one vessel to produce clean gas from biomass. Waste Manag. 2018, 71, 792-800. [CrossRef] [PubMed]

18. Molino, A.; Chianese, S.; Musmarra, D. Biomass gasification technology: The state of the art overview. J. Energy Chem. 2016, 25, 10-25. [CrossRef]

19. Savuto, E.; Di Carlo, A.; Gallucci, K.; Di Giuliano, A.; Rapagnà, S. Steam gasification of lignite and solid recovered fuel (SRF) in a bench scale fluidized bed gasifier. Waste Manag. 2020, 114, 341-350. [CrossRef] [PubMed]

20. European Comission Innovation and Networks Executive Agency. Available online: https://ec.europa.eu/inea/en/connectingeurope-facility/cef-transport/projects-by-country/multi-country/2014-eu-tm-0196-s (accessed on 23 March 2021).

21. Treatment of Absorbent Hygiene Products for Improved Recycling of Materials I Green Best Practice Community. Available online: https:/ / greenbestpractice.jrc.ec.europa.eu/node/131\#bemp_general_title_id (accessed on 23 March 2021).

22. Waldheim, L. Gasification of Waste for Energy Carriers-A Review. 2018. Available online: https://www.etipbioenergy.eu/ databases/reports/353-gasification-of-waste-for-energy-carriers-a-review (accessed on 23 March 2021).

23. Deliverable Number 1.7-Blueprint for the Replication of the AHP Pretreatment Technol; Establishing a Multi-Purpose Biorefinery for the Recycling of the Organic Content of AHP Waste in Circular Economy Domain Grant Agreement No.: 745746. Available online: https: / / www.embraced.eu/repository /EMBRACED_D1.7_Blueprint_DEF.pdf (accessed on 23 March 2021).

24. Mendoza, J.M.F.; D’Aponte, F.; Gualtieri, D.; Azapagic, A. Disposable baby diapers: Life cycle costs, eco-efficiency and circular economy. J. Clean. Prod. 2019, 211, 455-467. [CrossRef]

25. Kashyap, P.; Ko Win, T.; Visvanathan, C. Absorbent Hygiene Products-An emerging urban waste management issue. In Proceedings of the Asia-Pacific Conference on Biotechnology for Waste Conversion 2016, Hong Kong, China, 5-8 December 2016.

26. Arena, U.; Ardolino, F.; Gregorio, F.D.I. Sustainability of an Integrated Recycling Process of Absorbent Hygiene Products. In Proceedings of the 15th International Waste Management and Landfill Symposium, Cagliari, Italy, 5-9 October 2015.

27. Gerina-Ancane, A.; Eiduka, A. Research and analysis of Absorbent Hygiene Product (AHP) recycling. In Proceedings of the Engineering for Rural Development, Jelgava, Latvia, 25-27 May 2016; Volume 2016, pp. 904-910.

28. Khanyile, A.; Caws, G.C.; Nkomo, S.L.; Mkhize, N.M. Characterisation study of various disposable diaper brands. Sustainability 2020, 12, 437. [CrossRef]

29. Khoo, S.C.; Phang, X.Y.; Ng, C.M.; Lim, K.L.; Lam, S.S.; Ma, N.L. Recent technologies for treatment and recycling of used disposable baby diapers. Process Saf. Environ. Prot. 2019, 123, 116-129. [CrossRef]

30. Roddy, D.J.; Manson-Whitton, C. Biomass Gasification and Pyrolysis. In Comprehensive Renewable Energy-Biomass E Biofuels 2012; Elsevier: Amsterdam, The Netherlands, 2012; Volume 5, ISBN 9780080878737.

31. Bassano, C.; Deiana, P.; Ricci, G.; Veca, E.; Rse, R. Analisi Termogravimetrica su Campioni di Carbone. 2009. Available online: https:/ / docplayer.it/2987461-Analisi-termogravimetrica-su-campioni-di-carbone.html (accessed on 23 March 2021).

32. BS EN 15414-3:2011Solid Recovered Fuels. Determination of Moisture Content Using the Oven Dry Method. Moisture in General Analysis Sample. Available online: https:/ / www.en-standard.eu/din-en-15414-3-solid-recovered-fuels-determinationof-moisture-content-using-the-oven-dry-method-part-3-moisture-in-general-analysis-sample/ (accessed on 23 March 2021).

33. BS 1016-104.4-1998: Methods for Analysis and Testing of Coal and Coke. Proximate Analysis. Determination of ash. Available online: https: / / shop.bsigroup.com/ProductDetail/?pid=000000000030013765 (accessed on 23 March 2021).

34. Ambiente Italia s.r.l. Analisi Ambientale della Raccolta e del Riciclo di Prodotti Sanitari Assorbenti Risultati Sintetici. Available online: https:/ / www.senato.it/application/xmanager/projects/leg17/attachments/documento_evento_procedura_commissione/ files/000/000/636/Documentazione_FATER.pdf (accessed on 23 March 2021).

35. Okamoto, H. Supplemental Literature Review of Binary Phase Diagrams: Ag-Nd, Ag-Zr, Al-Nb, B-Re, B-Si, In-Pt, Ir-Y, Na-Si, Na-Zn, Nb-P, Nd-Pt, and Th-Zr. J. Phase Equilibria Diffus. 2014, 35, 636-648. [CrossRef]

36. Di Giuliano, A.; Lucantonio, S.; Gallucci, K. Devolatilization of Residual Biomasses for Chemical Looping Gasification in Fluidized Beds Made Up of Oxygen-Carriers. Energies 2021, 14, 311. [CrossRef]

37. Scala, F. Particle agglomeration during fluidized bed combustion: Mechanisms, early detection and possible countermeasures. Fuel Process. Technol. 2018, 171, 31-38. [CrossRef]

38. Gibilaro, L.G. Fluidization-Dynamic; Butterworth-Heinemann: Oxford, UK, 2001; ISBN 978-0-7506-5003-8. Available online: https: / /books.google.co.jp/books?hl=zh-CN\&lr=\&id=RlZutdBFy4sC\&oi=fnd\&pg=PP1\&dq=Gibilaro,+L.G.+FluidizationDynamic\%3B+Butterworth-Heinemann:+2001\%3B+ISBN+978-0-7506-5003-8, +doi:10.1016/B978-0-7506-5003-8.X5000-9.\&ots= Jn_kGOQKRB\&sig=IisegBeCakEykL43CA6MirBVotk\&redir_esc=y\#v=onepage\&q\&f=false (accessed on 23 March 2021). [CrossRef]

39. Basu, P. Combustion and Gasification in Fluidized Beds; CRC Press/Taylor \& Francis: Abingdon, UK, 2006 ; ISBN 9780849333965.

40. Green, D.W.; Robert, H.P. Perry's Chemical Engineers' Handbook, 8th ed.; McGraw-Hill: New York, NY, USA, 2017; ISBN 978007142294.

41. Namkung, H.; Xu, L.H.; Kim, C.H.; Yuan, X.; Kang, T.J.; Kim, H.T. Effect of mineral components on sintering of ash particles at low temperature fouling conditions. Fuel Process. Technol. 2016, 141, 82-92. [CrossRef] 